\title{
ARTYKULY - ARTICLES - PAPERS
}

„TURYZM”, t. 10, z. 1, 2000

Beata Krakowiak

CHARAKTERYSTYKA RUCHU TURYSTYCZNEGO

W PARKACH NARODOWYCH KARPAT ZACHODNICH TYPY FUNKCJONALNE PARKÓW

LA CARACTÉRISTIQUE DU MOUVEMENT TOURISTIQUE DANS LES PARCS NATIONAUX DES KARPATES D'OUEST TYPES FONCIONNELS DES PARCS

A DESCRIPTION OF THE TOURIST TRAFFIC IN THE WEST CARPATHIAN NATIONAL PARKS THE FUNCTIONAL TYPES OF PARKS

Artykuł dotyczy funkcji turystycznej pięciu parków narodowych znajdujących się w Karpatach Zachodnich. Za podstawowy miernik tej funkcji uznany został ruch turystyczny i jego elementy - wielkość, sezonowość, cechy społeczno-demograficzne, zasięg przestrzenny, częstotliwość i motywy przyjazdów, długość pobytu. W podsumowaniu autorka podejmuje próbę określenia typów funkcjonalnych parków narodowych tworzących badaną grupę.

\section{WPROWADZENIE}

Obszary górskie, w tym Karpaty, od bardzo dawna stanowiły punkt docelowy, lub choćby tranzytowy, wyjazdów. Przyjeżdżano tu zarówno w celach czysto naukowych czy służbowych, jak i turystycznych. Początki rozwoju ruchu turystycznego w Karpatach Polskich w dużym stopniu związane były z podróżami odbywanymi do uzdrowisk (G r o c h, K u r e k 1995). W XVII i XVIII w. licznie odwiedzana była $\mathrm{m}$. in. Szczawnica, z czasem zainteresowano się także Zakopanem i Rabką (XIX w.). Dzięki swoim walorom Karpaty stały się atrakcyjne nie tylko pod względem uzdrowiskowym, ale i poznawczym. Celem podróży były głównie Tatry, a także Pieniny i Beskidy. 
Intensywne użytkowanie gór miało jednak swoje negatywne konsekwencje. W celu nie dopuszczenia do nadmiemej ich eksploatacji powstały pierwsze obszary chronione na terenie Karpat (Tatry, Pieniny), które dały początek późniejszym parkom narodowym. Obecnie w obrębie omawianego obszaru znajduje się sześć parków narodowych: Babiogórski, Bieszczadzki, Gorczański, Magurski, Pieniński, Tatrzański (rys. 1).

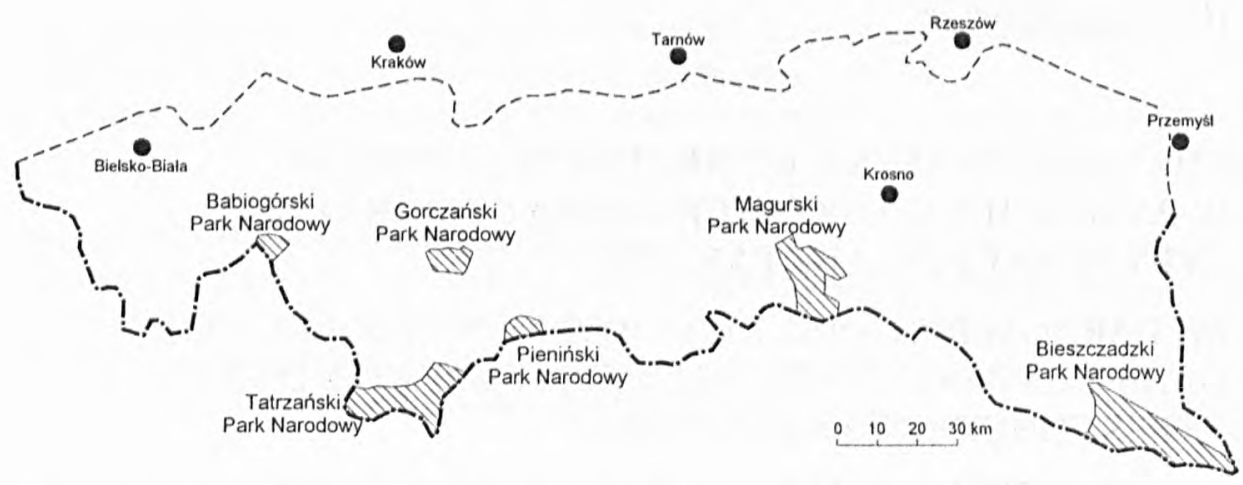

Rys. I. Polskie parki narodowe w granicach Karpat - stan w roku 1996 (D e n i s i u k 1995)

Dessin 1. Les parcs nationaux polonais dans les frontiéres des Karpates - état en 1996

(D e n i s i k 1995)

Celem niniejszej pracy jest charakterystyka zagadnień związanych z funkcją turystyczną parków narodowych znajdujących się w granicach Karpat Zachodnich (tym samym, w analizie nie uwzględniono Bieszczadzkiego Parku Narodowego), a najważniejszym miernikiem tej funkcji - ruch turystyczny. Podstawą analizy są dane statystyczne pochodzące $z$ dyrekcji parków narodowych, Krajowego Zarządu Parków Narodowych oraz ankiety przeprowadzone z turystami w czasie badań terenowych w $1996 \mathrm{r}$.

\section{WIELKOŚĆ RUCHU TURYSTYCZNEGO}

Z materiałów dotyczących 1996 r. (tab. I) wynika, że parki narodowe w Karpatach Zachodnich odwiedziło ok. $3 \mathrm{~m} / \mathrm{n}$ osób, co stanowi ok. 37\% ogólnego ruchu turystycznego w polskich parkach narodowych. Otrzymana wartość wydaje się być bardzo wysoka, tym bardziej, że ogólna powierzchnia parków narodowych w Karpatach Zachodnich stanowi ok. 17\% powierzchni wszystkich parków narodowych w Polsce (K r a k o w i a k 1999). W obrębie badanej grupy 
parków zaznacza się silne zróżnicowanie pod względem liczby odwiedzających. Obszarem najliczniej penetrowanym jest Tatrzański Park Narodowy, do którego przybyło w 1996 r. ok. 2,5 mln turystów, co stanowi ok. 83\% wszystkich odwiedzających w tym czasie parki narodowe w Karpatach Zachodnich. Wysoka pozycja tego parku wynika z kilku przyczyn. Po pierwsze, Tatrzański Park Narodowy zajmuje niekwestionowane pierwsze miejsce wśród wszystkich polskich parków narodowych pod względem atrakcyjności przyrodniczej (w waloryzacji Denisiuka - 6,9 punktów na 7 punktów możliwych; D e n i s i u k 1995). Poza tym, jest to jeden z najstarszych regionów turystycznych, a ponadto jeden z najstarszych parków narodowych w Polsce. Oprócz schronisk i licznych szlaków turystycznych na terenie Tatrzańskiego Parku Narodowego dobre zagospodarowanie charakteryzuje także jego otoczenie. Obecnie samo tylko Zakopane posiada ok. 15 tys. miejsc noclegowych, z czego ok. $80 \%$ to całoroczne (Rocznik... 1997). Przyjazdom sprzyja także dobra dostępność tego terenu i jego wewnętrzne skomunikowanie. Zainteresowanie Tatrami może być też konsekwencją niedoinwestowania innych obszarów, niskiego poziomu wiedzy krajoznawczej oraz słabej organizacji ruchu turystycznego ( $\mathrm{R}$ o g a l e w s k i 1975).

Tabela I

Wielkość ruchu turystycznego w parkach narodowych Karpat Zachodnich w $1996 \mathrm{r}$.

La grandeur du mouvement touristique dans les parcs nationaux des Karpates d'Ouest (1996)

\begin{tabular}{|l|r|r|r|r|}
\hline \multirow{2}{*}{$\begin{array}{c}\text { Nazwa parku } \\
\text { narodowego }\end{array}$} & \multicolumn{4}{|c|}{ Liczba turystów } \\
\cline { 2 - 5 } & w tys. & w \% & na $1 \mathrm{~km}^{2}$ & na 1 km szlaku \\
\hline Babiogórski (BPN) & 49 & 1,62 & 2,83 & 1531 \\
Gorczański (GPN) & 45 & 1,49 & 0,67 & 703 \\
Magurski (MPN) & 20 & 0,66 & 0,10 & 298 \\
Pieniński (PPN) & 400 & 13,27 & 17,05 & 12121 \\
Tatrzański (TPN) & 2500 & 82,94 & 11,81 & 10204 \\
\hline Ogółem & 3014 & 100,00 & 5,80 & 6834 \\
\hline
\end{tabular}

Ź r ó d lo: Na podstawie danych Krajowego Zarządu Parków Narodowych.

Drugim pod względem wielkości ruchu turystycznego jest Pieniński Park Narodowy. W 1996 r. odwiedziło go ok. 400 tys. osób, co daje ok. 13\% wszystkich turystów przyjeżdżających do parków narodowych w Karpatach Zachodnich. Podobnie jak w przypadku Tatrzańskiego Parku Narodowego, największym magnesem Pienin są walory przyrodnicze (6,5 punktu). Atrakcją dla turystów są tu zarówno najwyższe szczyty (Trzy Korony, Sokolica), będące jednocześnie punktami widokowymi, jak również przełom Dunajca i odbywający się tu spływ, który ma już ok. 150-letnią tradycję. Atutem Pienin jest także to, że ze 
względu na wysokości są one dostępne praktycznie dla każdego, bez specjalnego przygotowania. Mówiąc o turystyce na obszarze parku nie sposób pominąc faktu, że przyjazdy turystyczne w Pieniny mają odległą tradycję, podobnie zresztą jak ochrona przyrody. Nie bez znaczenia dla turystów jest również wielkość bazy noclegowej w otoczeniu parku. W samej tylko Szczawnicy jest ok. 4800 miejsc noclegowych, w tym ok. 1300 sezonowych. Znanym ośrodkiem jest także Krościenko, posiadające ok. 2200 miejsc (w tym ok. 800 sezonowych) oraz Sromowce, Jaworki, Czorsztyn (J a r c z e w s k a, S i e j k ow s k a 1997). O znaczeniu infrastruktury nie decyduje tylko jej wielkość, ale także jej charakter. Większość obiektów jest ogólnodostępna, a korzystanie z nich jest możliwe w ciagu całego roku.

Pozostałe parki przyjęły od ok. 20 tys. (Magurski) do ok. 45-49 tys. turystów (Gorczański, Babiogórski), co stanowi odpowiednio $0,66 \%$ i 1,49-1,62\% gości analizowanych karpackich parków narodowych. Wraz z wcześniej wymienionymi obszarami, grupę najstarszych parków narodowych w Polsce tworzy Babiogórski Park Narodowy. Pod względem atrakcyjności przyrodniczej (5,6 punktu) plasuje się on jako trzeci, w badanej grupie parków, po Tatrzańskim i Pienińskim Parku Narodowym. Mimo dobrego zagospodarowania pod względem szlaków turystycznych park ten posiada niewielką liczbę miejsc noclegowych, dlatego też turyści muszą szukać noclegów poza nim. W odróżnieniu od wymienionych już parków, w sąsiedztwie Babiogórskiego Parku Narodowego nie ma miast odgrywających w podróżach turystycznych taką rolę, jak Zakopane czy Szczawnica. Funkcję „miejscowości wypadowych” na Babią Górę spełniają wsie turystyczne, wśród których najważniejszą rolę odgrywa Zawoja. Dysponuje ona w sumie ok. 1600 miejscami noclegowymi, z czego ok. $72 \%$ to obiekty całoroczne (Rocznik... 1997).

Podobną wielkość ruchu turystycznego notuje się także na terenie Gorczańskiego Parku Narodowego, choć w odniesieniu do powierzchni czy długości szlaków pieszych, obszar ten wypada gorzej od Babiogórskiego Parku Narodowego. W wielokrotnie już wspominanej waloryzacji, wartość przyrodniczą parku oceniono tylko na 3,8 punktu, co oznacza, że park ten zajmuje ostatnie miejsce na liście tego typu obszarów na terenie Karpat Zachodnich. Do pewnego stopnia wynika to z faktu, że na obszarze Gorczańskiego Parku Narodowego nie ma atrakcji na miarę Morskiego Oka, Doliny Kościeliskiej, spływu Dunajcem czy innych, spotykanych w wymienionych wcześniej parkach karpackich. Drugim ważnym powodem wydaje się być także to, że Gorczański Park Narodowy jest stosunkowo młody, a przez to i mniej popularny. Mimo relatywnie dobrej dostępności komunikacyjnej (autobusy, blisko przechodząca kolej, liczne szlaki), w penetrowaniu parku nie pomaga skomunikowanie miejscowości położonych na jego obrzeżu. Również baza noclegowa w okolicach parku ma w zakresie struktury ograniczony charakter, gdyż dominują w niej ośrodki zakładowe, bardzo często sezonowe. Najlepsze zaplecze dla parku pod tym względem 
stwarza Rabka i Nowy Targ. Wszystko to decyduje o tym, że park ten nie jest celem masowych podróży, ale stanowi atrakcję dla wybranej grupy osób, tzn. dla turystów bardziej samodzielnych, dla których sztandarowe atrakcje nie są przedmiotem zainteresowania. Mały ruch turystyczny jest tu też prawdopodobnie skutkiem położenia pomiędzy dwoma silnie oddziałującymi parkami narodowymi - Pienińskim i Tatrzańskim.

Podobne uwagi dotyczyć mogą także Magurskiego Parku Narodowego, najmniej licznie odwiedzanego, dla którego wartość ruchu turystycznego oszacowana na poziomie ok. 20000 osób wydaje się i tak zawyżona. Na małą frekwencję w tym parku składa się jednocześnie kilka elementów. Po pierwsze, Beskid Niski, na terenie którego położony jest park, jest terenem stosunkowo mało odwiedzanym, a renomowane miejscowości tego regionu są znacznie oddalone od granic parku. Pomimo posiadanych przez niego walorów przyrodniczych (4,0 punkty) przyjazdom do parku nie sprzyja ani dostępność komunikacyjna zewnętrzna ( $\mathrm{z}$ wyjątkiem szlaków), ani skomunikowanie wewnętrzne. Również baza noclegowa $w$ otoczeniu parku pozostawia wiele do życzenia, ze względu na ograniczone możliwości korzystania z niej (zamknięty charakter, sezonowość, niski standard). Ponadto, sytuacji nie ułatwia młody wiek parku, którego konsekwencją są $\mathrm{m}$. in. surowe warunki w zakresie ogólnodostępnego zagospodarowania turystycznego.

Podsumowując analizę dotyczącą wielkości ruchu turystycznego w parkach narodowych Karpat Zachodnich należy zauważyć, że na jego rozmiary wplywa równocześnie kilka czynników. Do najważniejszych należą: wiek parku, jego atrakcyjność, zagospodarowanie i dostępność komunikacyjna.

\subsection{SEZONOWOŚĆ}

Analiza czasowego rozkładu ruchu turystycznego w parkach narodowych Karpat Zachodnich przeprowadzona została na podstawie wypisów z ksiąg meldunkowych prowadzonych w schroniskach, znajdujących się na terenie omawianych parków lub przy ich granicach.

Zgromadzone materiały pozwalają stwierdzić, że w badanych parkach zauważa się okresy podwyższonej aktywności turystycznej odpowiadające poszczególnym porom roku (tab. II, rys. 2). Okresem największej aktywności turystycznej jest lato. Od czerwca do sierpnia przyjeżdża ok. 39\% turystów do Gorczańskiego Parku Narodowego, ok. 48\% do Babiogórskiego i Tatrzańskiego Parku Narodowego oraz ok. 54-57\% turystów do Pienińskiego i Magurskiego Parku Narodowego. W odniesieniu do ostatnio wymienionych parków wzrost frekwencji przypisać należy dwóm różnym czynnikom. W Pienińskim Parku Narodowym wzrost ruchu turystycznego w miesiącach letnich nawiązuje do czasu trwania jednej z największych atrakcji regionu - spływu Dunajcem, który ma cha- 
Sezonowość ruchu turystycznego w schroniskach na terenie parków narodowych w Karpatach Zachodnich (1996 r.)

La caractère saisonnier du mouvement touristique dans les abris sur le terrain des Karpates d'Ouest 1996

\begin{tabular}{|c|c|c|c|c|c|c|c|c|c|c|c|c|c|c|c|}
\hline \multirow[t]{2}{*}{ Miesiąc } & \multicolumn{3}{|c|}{ Babiogórski } & \multicolumn{3}{|c|}{ Gorczański } & \multicolumn{3}{|c|}{ Magurski } & \multicolumn{3}{|c|}{ Pieniński } & \multicolumn{3}{|c|}{ Tatrzański } \\
\hline & Osoby & $\%$ & $W_{S}^{*}$ & Osoby & $\%$ & $W_{S}^{*}$ & Osoby & $\%$ & $W s^{*}$ & Osoby & $\%$ & $W s^{*}$ & Osoby & $\%$ & $W s^{*}$ \\
\hline I & 71 & 1,51 & 18,16 & 221 & 2,96 & 35,47 & 30 & 3,65 & 44,12 & 32 & 0,46 & 5,56 & 1192 & 3,04 & 36,54 \\
\hline II & 350 & 7,45 & 8 & 138 & 1,85 & 22,15 & 70 & 8,50 & 102,94 & 189 & 2,74 & 32,81 & 2327 & 5,94 & 71,34 \\
\hline III & 86 & 1,83 & 21,99 & 318 & 4,26 & 51,04 & 7 & 0.85 & 10,29 & 55 & 0,80 & 9,55 & 1789 & 4,57 & 54,84 \\
\hline IV & 103 & 2,19 & 26,34 & 55 & 0,74 & 8,83 & 35 & 4,25 & 51,47 & 356 & 5,15 & 61,80 & 2203 & 5,63 & 67,54 \\
\hline V & 471 & 10,03 & 120,46 & 1129 & 15,11 & 181,22 & 115 & 13,97 & 169,12 & 945 & 13,68 & 164,06 & 1601 & 4,09 & 49,08 \\
\hline VI & 617 & 13,14 & 157,80 & 577 & 7,72 & 92,62 & 181 & 21,99 & 266,18 & 999 & 14,46 & 173,43 & 3607 & 9,21 & 110,58 \\
\hline VII & 926 & 19,72 & 236,22 & 1510 & 20,21 & 242,38 & 114 & 13,85 & 167,65 & 1139 & 16,49 & 197,70 & 7313 & 18,68 & 224,19 \\
\hline VIII & 730 & 15,55 & 186,70 & 820 & 10,98 & 131,62 & 176 & 21,38 & 258,82 & 1577 & 22,83 & 273,78 & 7934 & 20,27 & 243,20 \\
\hline IX & 412 & 8,77 & 105,37 & 773 & 10,35 & 124,08 & 51 & 6,20 & 75,00 & 623 & 9,02 & 108,16 & 6486 & 16,57 & 198,84 \\
\hline $\mathrm{X}$ & 585 & 12,46 & 149,62 & 984 & 13,17 & 157,94 & 19 & 2,31 & 27,94 & 740 & 10,71 & 128,47 & 2789 & 7,12 & 85,50 \\
\hline XI & 182 & 3,88 & 46,55 & 21 & 0,28 & 3,37 & 19 & 2,31 & 27,94 & 133 & 1,93 & 23,09 & 738 & 1,89 & 22,62 \\
\hline XII & 163 & 3,47 & 41,69 & 925 & 12,38 & 148,48 & 6 & 0,73 & 8,82 & 119 & 1,72 & 20,66 & 1168 & 2,98 & 35,81 \\
\hline Ogółem & 4696 & 100,00 & $\mathrm{x}$ & 7471 & 100,00 & $\mathrm{x}$ & 823 & 100,00 & $\mathrm{x}$ & 6907 & 100,00 & $\mathrm{x}$ & 39147 & 100,00 & $\mathrm{x}$ \\
\hline Amplituda & $x$ & 18,21 & $x$ & $\mathrm{x}$ & 19,93 & $\mathrm{x}$ & $\mathrm{x}$ & 21,26 & $\mathrm{x}$ & $\mathrm{x}$ & 22,37 & $\mathrm{x}$ & $\mathrm{x}$ & 18,38 & $\mathrm{x}$ \\
\hline
\end{tabular}

*Ws - wskaźnik sezonowości.

Ź r ó d fo: Opracowanie własne na podstawie ksiąg meldunkowych w schroniskach. 
rakter wybitnie sezonowy. Z kolei w Magurskim Parku Narodowym na kształtowanie się ruchu turystycznego wywiera wpływ sezonowy charakter bazy noclegowej w otoczeniu parku.

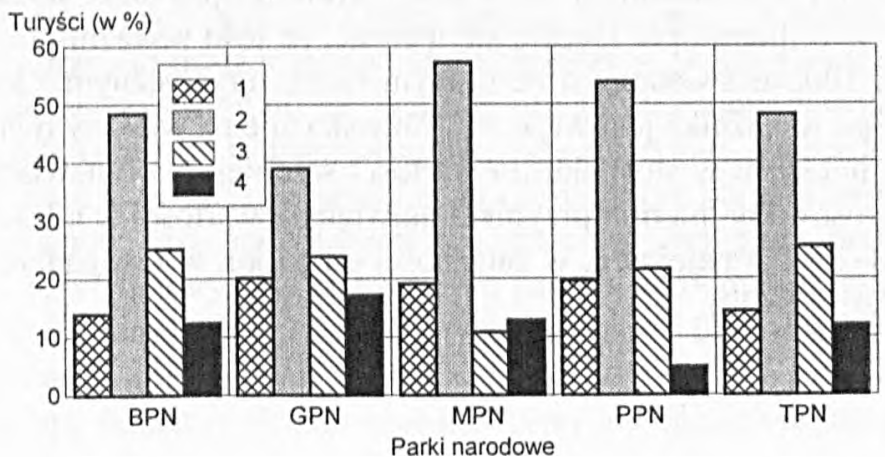

Rys. 2. Sezonowość ruchu turystycznego w schroniskach na terenie parków narodowych w Karpatach Zachodnich wg pór roku (1996 r.)

1 - wiosna, 2 - lato, 3 -jesień, 4 - zima

Dessin 2. Le caractère saisonier du mouvement touristique dans les abris sur le terrain des parcs nationaux dans les Karpates d'Ouest selon les saisons de l'année (1996)

1 - printemps, 2 - été, 3 - automme, 4 - hiver

Następne pod względem wielkości ruchu turystycznego pory roku to jesień i wiosna. W stosunku do lata, w tych porach roku notuje się spadek ruchu turystycznego o co najmniej połowę.

Najniższą frekwencje przyjazdów notuje się zimą; w tym czasie przyjeżdża do parków narodowych w Karpatach Zachodnich ok. 12-17\% turystów (wyjątek to Pieniński Park Narodowy).

Nawiązując do pór roku, ale biorąc także pod uwagę ciągłość ruchu turystycznego i kulminację przyjazdów, można mówić o dwóch wyraźnych sezonach turystycznych, krótszym - zimowym, przypadającym na grudzień, styczeń i luty, oraz dłuższym - letnim, który zaczyna się w miesiącach wiosennych; kulminację przyjazdów osiąga latem, a kończy się po okresie jesiennych wycieczek. W sumie, od wiosny do jesieni przybywa ok. 79\% turystów do Gorczańskiego oraz ok. $84-86 \%$ do Tatrzańskiego i Babiogórskiego Parku Narodowego. Największą liczbę przyjazdów w tym czasie notuje się jednak na terenie Pienińskiego i Magurskiego Parku Narodowego (ok. 94\%). O nierównomiernym rozkładzie ruchu turystycznego w ciągu roku świadczy także amplituta sezonowości (tab. III), wyrażająca różnicę pomiędzy ruchem turystycznym w skrajnych miesiącach (najczęściej lipiec, sierpień i listopad, styczeń). Jej wartość waha się 
od ok. 18,5\% (Babiogórski i Tatrzański Park Narodowy) do ok 22,5\% (Pieniński Park Narodowy). Wprawdzie różnice te nie są zbyt duże, niemniej świadczą o bardziej równomiernym rozkładzie ruchu turystycznego w Babiogórskim i Tatrzańskim Parku Narodowym, co wskazywać może na większą ich atrakcyjność w skali roku. Potwierdzeniem omawianego zjawiska jest także wskaźnik sezonowości $\left(W_{s}\right)$. W literaturze zwykło się uważać, że jeśli wskaźnik ten osiąga wartość $W_{s}=100$, to świadczy o znaczącym ruchu turystycznym. Oczywiście, im wartość tego wskaźnika jest większa, tym wskazuje na większy ruch turystyczny w danym miesiącu w stosunku do wartości średniej. Na omawianym obszarze (tab. III) stosowany miernik przybiera największe wartości w miesiącach letnich ( $\left.W_{s}=240-270\right)$, a najniższe, w zależności od parku, w listopadzie, grudniu lub styczniu $\left(W_{s}=5-20\right)$.

Tabela III

Sezonowość ruchu turystycznego w schroniskach na terenie parków narodowych w Karpatach Zachodnich wg pór roku (1996 r.)

Le caractère saisonier du mouvement touristique dans les abris sur le terrain des Karpates d'Ouest selon les saisons de l'année (1996)

\begin{tabular}{|l|r|r|c|c|r|r|r|r|r|r|}
\hline \multirow{2}{*}{$\begin{array}{c}\text { Pora } \\
\text { roku }\end{array}$} & \multicolumn{2}{|c|}{ Babiogórski } & \multicolumn{2}{c|}{ Gorczański } & \multicolumn{2}{c|}{ Magurski } & \multicolumn{2}{c|}{ Pieniński } & \multicolumn{2}{c|}{ Tatrzański } \\
\cline { 2 - 11 } & $\begin{array}{c}\text { Liczba } \\
\text { osób }\end{array}$ & $\%$ & $\begin{array}{c}\text { Liczba } \\
\text { osób }\end{array}$ & $\%$ & $\begin{array}{c}\text { Liczba } \\
\text { osób }\end{array}$ & $\%$ & $\begin{array}{c}\text { Liczba } \\
\text { osób }\end{array}$ & $\%$ & $\begin{array}{c}\text { Liczba } \\
\text { osób }\end{array}$ & $\%$ \\
\hline Wiosna & 660 & 14,05 & 1502 & 20,10 & 157 & 19,07 & 1356 & 19,63 & 5593 & 14,29 \\
Lato & 2273 & 48.40 & 2907 & 38,91 & 471 & 7,23 & 3715 & 53,79 & 18854 & 48,16 \\
Jesień & 1179 & 25,11 & 1778 & 23,79 & 89 & 10,81 & 1496 & 21,66 & 10013 & 25,58 \\
Zima & 584 & 12.44 & 1284 & 17,19 & 106 & 12,88 & 340 & 4,92 & 4687 & 11,97 \\
\hline Ogólem & 4696 & 100,00 & 7471 & 100,00 & 823 & 100,00 & 6907 & 100,00 & 39147 & 100,00 \\
\hline
\end{tabular}

Ź r ó d l o: Opracowanie wlasne na podstawie ksiąg meldunkowych w schroniskach.

\subsection{CECHY SPOŁECZNO-DEMOGRAFICZNE}

Badanie struktur społeczno-demograficznych turystów odwiedzających analizowane parki narodowe ma szczególne znaczenie dla charakterystyki ruchu turystycznego omawianych obszarów. O ile wielkość ruchu turystycznego wskazuje na rozmiary zjawiska, a sezonowość na jego rozkład w czasie, o tyle cechy społeczno-demograficzne dostarczają informacji o tym, kim są osoby przyjeżdżające $w$ badane regiony, a tym samym dla kogo badane parki są atrakcyjne.

W tej części artykułu omówione zostaną: struktura wieku turystów, wykształcenie, oraz pochodzenie ze względu na jednostkę osadniczą. 


\subsubsection{STRUKTURA WIEKU}

W celu scharakteryzowania struktury wieku turystów, autorka podzieliła wszystkich odwiedzających parki narodowe w Karpatach Zachodnich na trzy grupy: młodzież, dorosłych i emerytów (tab. IV, rys. 3). Do pierwszej z nich zaliczono potencjalnych uczniów i studentów, a więc osoby w wieku 18-24 lat. Za dorosłych przyjęto uważać osoby, które ukończyły 24 lata (wiek ukończenia studiów) i nie przekroczyły 60 lat życia. Grupa ta utożsamia zawodowo czynnych. Pozostałe osoby zakwalifikowano do grupy emerytów. Zadecydował o tym fakt, że w Polsce na emeryturę przechodzą osoby, które przepracowały średnio 35 lat. Relacje pomiędzy przedstawicielami poszczególnych grup obrazuje rys. 3 . Ukazuje on, że wśród turystów omawianych parków narodowych dominują osoby dorosłe, które stanowią ok. 52-55\% w Tatrzańskim, Babiogórskim i Pienińskim Parku Narodowym oraz ok. 60\% w Gorczańskim Parku Narodowym. Duży odsetek tej grupy thumaczy liczba roczników reprezentujących tę kategorię.

Tabela IV

Grupy wiekowe turystów odwiedzających parki narodowe w Karpatach Zachodnich (1996 r.)

Les groupes de touristes visitant les parcs nationaux des Karpates d’Ouest sclon leur âge 1996

\begin{tabular}{|l|c|c|c|c|c|c|c|c|}
\hline \multirow{2}{*}{ Park Narodowy } & \multicolumn{2}{|c|}{ Mlodzież } & \multicolumn{2}{c|}{ Dorośli } & \multicolumn{2}{c|}{ Emeryci } & \multicolumn{2}{c|}{ Ogółem } \\
\cline { 2 - 9 } & $\begin{array}{c}\text { liczba } \\
\text { osób }\end{array}$ & $\%$ & $\begin{array}{c}\text { liczba } \\
\text { osób }\end{array}$ & $\%$ & $\begin{array}{c}\text { liczba } \\
\text { osób }\end{array}$ & $\%$ & $\begin{array}{c}\text { liczba } \\
\text { osób }\end{array}$ & $\%$ \\
\hline Babiogórski & 104 & 41,76 & 136 & 54,62 & 9 & 3,61 & 249 & 100,00 \\
Gorczański & 115 & 39,00 & 178 & 60,33 & 2 & 0,67 & 295 & 100,00 \\
Magurski & 127 & 53,14 & 108 & 45,20 & 4 & 1,67 & 239 & 100,00 \\
Pieniński & 195 & 43,92 & 247 & 55,63 & 2 & 0,45 & 444 & 100,00 \\
Tatrzański & 812 & 45,57 & 932 & 52,30 & 38 & 2,13 & 1782 & 100,00 \\
\hline
\end{tabular}

ź r ó d l o: Opracowanie wlasne na podstawie ankiet.

Relatywnie mniej liczną grupę stanowi młodzież. Biorąc jednak pod uwagę fakt, że grupa ta obejmuje tylko siedem roczników, jej udział - kształtujący się na poziomie ok. $40-45 \%$ badanej populacji w Gorczańskim, Babiogórskim, Pienińskim i Tatrzańskim Parku Narodowym i ok. 53\% w Magurskim Parku Narodowym - należy uznać za bardzo duży.

Znikomy odsetek charakteryzuje ostatnią, najstarszą wiekowo grupę. W zależności od parku jej udział wynosi się od ok. $0,5 \%$ do ok. 3,5\%. Mały udział przedstawicieli tej grupy ma związek z mniejszą ich mobilnością, a ponadto z faktem, że dla osób starszych, ze względów zdrowotnych, góry stanowią w mniejszym stopniu cel wyjazdów turystycznych. 


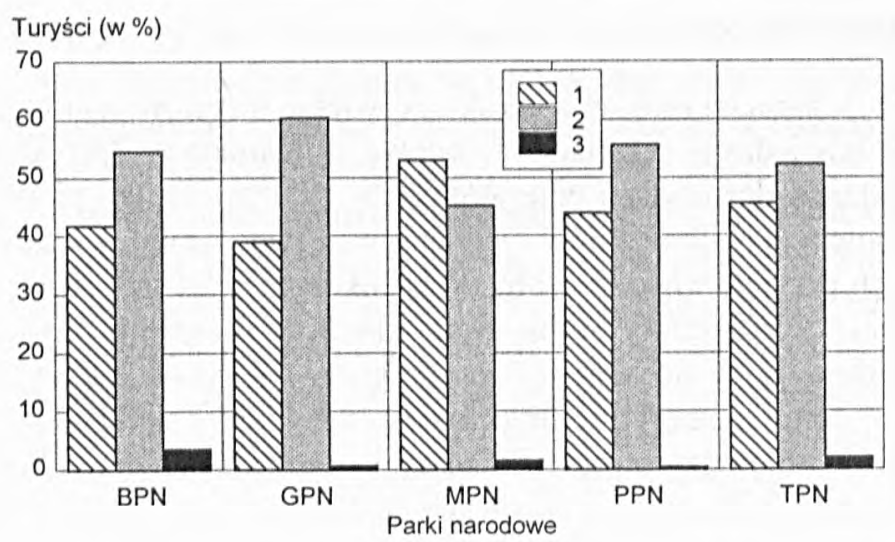

Rys. 3. Struktura wieku turystów odwiedzających parki narodowe w Karpatach Zachodnich (1996 r.)

1 - mlodzież, 2 - dorośli, 3 - emeryci

Dessin 3. La structure de l'âge des touristes visitant les parcs nationaux dans les Karpates d'Ouest (1996)

1 -jeunes gens, 2 - adultes, 3 - retraités

Podsumowując należy stwierdzić, że zdecydowanie najmłodszą „klientelę” posiada Magurski Park Narodowy. Biorąc pod uwagę warunki, jakie oferuje ten obszar (w sensie zagospodarowania turystycznego, dostępności komunikacyjnej), można pokusić się o stwierdzenie, że młodzież spełnia niejako pionierską misję w tym nowo powstałym parku.

Pozostałe cztery parki (Babiogórski, Gorczański, Pieniński, Tatrzański) uznać należy za obszary atrakcyjne przede wszystkim dla ludzi dorosłych. Decyduje o tym lepsza dostępność tych parków (element ten liczy się zwłaszcza w podróżach rodzinnych, których uczestnikami są dzieci; podróże takie stanowią dość dużą część przyjazdów do wymienionych parków) oraz wielkość bazy noclegowej, jak również jej różnorodność (pozwala ona na pewien wybór, w zależności od oczekiwań i możliwości finansowych turystów).

\subsubsection{WYKSZTAŁCENIE}

Analiza wykształcenia turystów odwiedzających karpackie parki narodowe pozwala zauważyć, że najmniej liczne grupy w każdym z badanych parków tworzą osoby $z$ wykształceniem podstawowym i zawodowym. Ich udział wynosi odpowiednio od ok. 3,5 do $11 \%$ i od 2 do $6 \%$. (tab. V, rys. 4). Nieco większy udział charakterystyczny jest dla turystów z wykształceniem policealnym, którym legitymuje się ok. 8-10\% gości parków. Kolejne, pod względem liczebności grupy, składają się z osób z wykształceniem wyższym (ok. 30-40\%) i średnim 
Tabela V

Wykształcenie turystów odwiedzających parki narodowe w Karpatach Zachodnich (1996 r.)

L'instruction des touristes visitant les parcs nationaux des Karpates d'Ouest (1996)

\begin{tabular}{|l|r|r|r|r|r|r|r|r|r|r|}
\hline \multirow{2}{*}{$\begin{array}{c}\text { Wyksztal- } \\
\text { cenie }\end{array}$} & \multicolumn{2}{|c|}{ Babiogórski } & \multicolumn{2}{c|}{ Gorczański } & \multicolumn{2}{c|}{ Magurski } & \multicolumn{2}{c|}{ Pieniński } & \multicolumn{2}{c|}{ Tatrzański } \\
\cline { 2 - 11 } & l. o.* & \multicolumn{1}{c|}{$\%$} & I. o.* & \multicolumn{1}{c|}{$\%$} & l. o.* & \multicolumn{1}{c|}{$\%$} & 1. o.* & $\%$ & 1. o.* & \multicolumn{1}{c|}{$\%$} \\
\hline Podstawowe & 16 & 6,43 & 11 & 3,73 & 20 & 8,37 & 18 & 4,05 & 195 & 10,94 \\
Zawodowe & 14 & 5,62 & 12 & 4,06 & 11 & 4,60 & 10 & 2,25 & 73 & 4,10 \\
Średnie & 105 & 42,17 & 130 & 44,07 & 118 & 49,38 & 195 & 43,92 & 736 & 41,30 \\
Policealne & 23 & 9,24 & 23 & 7,80 & 19 & 7,95 & 46 & 10,36 & 175 & 9,82 \\
Wyższe & 91 & 36,54 & 119 & 40,34 & 71 & 29,7 & 175 & 39,40 & 603 & 33,82 \\
\hline Ogólem & 249 & 100,00 & 295 & 100,00 & 239 & 100,00 & 444 & 100,00 & 1782 & 100,00 \\
\hline
\end{tabular}

1. o, *-liczba osób.

Źr ó d f o: Opracowanie wlasne na podstawie badań ankietowych.

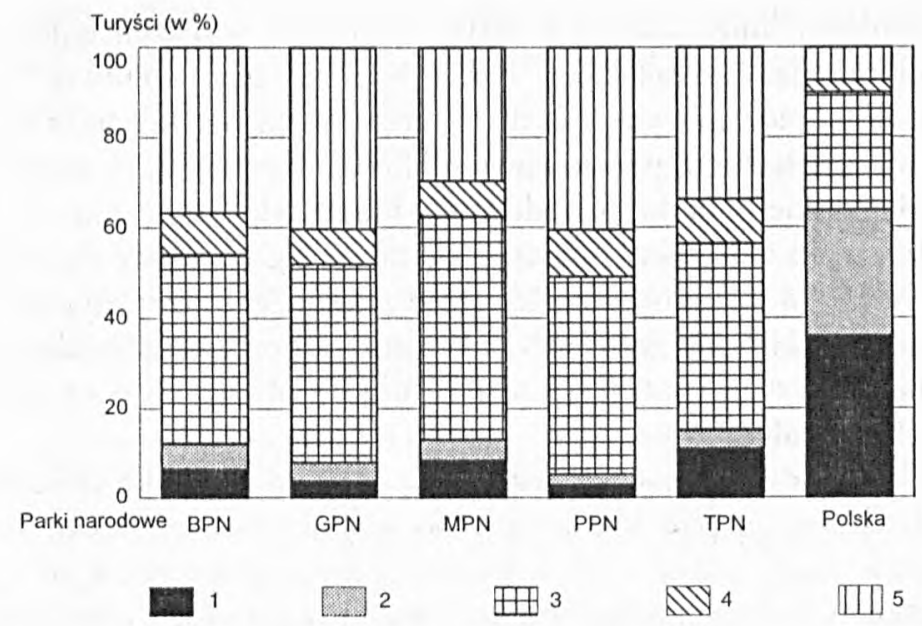

Rys. 4. Wyksztalcenie turystów odwiedzających parki narodowe w Karpatach Zachodnich (1996 r.)

1 - podstawowe, 2 - zawodowe, 3 - średnie, 4 - policealne, 5 - wyższe

Dessin 4. L'instruction des touristes visitant les parcs nationaux des Karpates (1996) 1- primaire, 2 - professionnelle, 3 - secondaire, 4-mi-supérieure, 5 -supérieure

(ok. 41-49\%). Ogółem, wykształcenie policealne i wyższe charakteryzuje od ok. 40\% (Magurski Park Narodowy) do ok. 50\% (Pieniński, Gorczański, Babiogórski Park Narodowy) turystów. Gdy dodać do tego osoby z wykształceniem śred- 
nim, okazuje się, że razem stanowią one od ok. $85 \%$ (Tatrzański) do $94 \%$ (Pieniński) turystów. Tak ukształtowany rozkład świadczy o zdecydowanej przewadze osób lepiej wykształconych w ogólnej liczbie turystów odwiedzających badane karpackie parki narodowe.

Istotą prowadzonej analizy, oprócz stwierdzenia ogólnych prawidłowości, jest również poszukiwanie podobieństw i różnic pomiędzy poszczególnymi parkami narodowymi. W aspekcie omawianego problemu zdecydowanie odmienny od pozostałych jest Magurski Park Narodowy. Na jego terenie zaznacza się największy udział osób z najniższym wykształceniem (podstawowe, zawodowe) oraz średnim. Ogółem stanowią one ok. $62 \%$ turystów odwiedzających ten park. Wyjaśnienia tego zjawiska poszukiwać należy w strukturze wiekowej turystów. Zgodnie $\mathrm{z}$ wcześniej przeprowadzoną analizą park ten, jako jedyny zreszta, określony został mianem parku ludzi młodych. Grupę młodzieży tworzyli tu uczniowie szkól średnich, pomaturalnych i studenci, którzy łącznie stanowili niewiele ponad $50 \%$ ogółu turystów. Porównanie obu przytoczonych wartości wskazuje, że to właśnie oni tworzą główną część grupy osób najsłabiej wykształconych.

Stosunkowo dużo osób z niższym i średnim wykształceniem zanotowano także na terenie Tatrzańskiego Parku Narodowego; stanowily one ok. 56\% wszystkich odwiedzających. Na tle tej grupy wyraźnie zaznacza się duży udział osób z wykształceniem podstawowym (11\%). Tworzą ją podobnie jak w przypadku Magurskiego Parku Narodowego, ludzie młodzi, uczniowie. Wśród osób z niższym wykształceniem znajdują się także legitymujący się wykształceniem zawodowym. Są to osoby dorosłe, które zakończyły już swoją edukację. Prawdopodobne wydaje się, że w przypadku miejsc powszechnie znanych i popularnych obecność tych osób jest częstsza niż na obszarach o niepotwierdzonych powszechnie walorach.

Turystów odwiedzających pozostałe parki (Babiogórski, Gorczański, Pieninski) charakteryzują podobne relacje pomiędzy poszczególnymi stopniami wykształcenia: mały udział osób z wykształceniem podstawowym i zawodowym (z wyjątkiem Babiogórskiego Parku Narodowego) oraz największy w badanej grupie parków udział osób dobrze wykształconych (wykształcenie wyższe).

Ciekawych wniosków dostarcza porównanie diagramów dotyczących wykształcenia osób w Polsce i turystów w poszczególnych parkach narodowych. Okazuje się, że relacje pomiędzy poszczególnymi stopniami wykształcenia turystów odwiedzających badany teren są dokładnym odwróceniem relacji, jakie charakterystyczne są dla mieszkańców całego kraju. Spośród blisko 40\% społeczeństwa polskiego legitymującego się wykształceniem średnim, policealnym i wyższym pochodzi ok. 85-95\% turystów ankietowanych na obszarze badanych parków narodowych. Natomiast z grupy Polaków z wykształceniem podstawowym i zawodowym liczącej nieco ponad $60 \%$, wywodzi się tylko ok. 5-15\% gości omawianych parków. Tendencja ta obserwowana jest też wśród turystów 
w innych regionach turystycznych kraju, co wytłumaczyć można większą aktywnością turystyczną osób lepiej wykształconych niż osób z niższym wykształceniem. Istotna jednak różnica pomiędzy badanymi obszarami a pozostałymi regionami sa inne proporcje obserwowane pomiędzy grupa $\mathrm{z}$ wykształceniem średnim a wyższym, które w obszarach nadmorskich czy jeziornych zwiększają się zdecydowanie na korzyść tej pierwszej, osiągając ok. 60-70\% populacji (K le is ch mid 1998).

\subsubsection{POCHODZENIE ZE WZGLĘDU NA JEDNOSTKĘ OSADNICZĄ}

Istotne dla charakterystyki ruchu turystycznego jest zdaniem autorki określenie: skąd, a dokładniej z jakiego środowiska społecznego wywodzą się goście odwiedzający parki narodowe w Karpatach Zachodnich. W tym celu analizie poddano miejsce zamieszkania turystów, w aspekcie jego statusu osadniczego (miasto, wieś) oraz wielkości (tab. VI). Okazuje się, że wśród turystów zdecydowanie dominują osoby mieszkające w miastach. Ich udział waha się od ok. $91 \%$ w Babiogórskim Parku Narodowym do 96\% w Pienińskim i Tatrzańskim Parku Narodowym. Mały udział ludności wiejskiej w wyjazdach turystycznych do omawianych parków ma związek $\mathrm{m}$. in. z jej warunkami ekonomicznymi, stylem życia, mentalnością, posiadanym czasem wolnym.

Tabela VI

Turyści odwiedzający parki narodowe w Karpatach Zachodnich wg jednostek osadniczych (1996)

Les touristes visitant les parcs nationaux des Karpates d'Ouest eu égard à l'unité de colonisation (1996)

\begin{tabular}{|c|c|c|c|c|c|c|c|c|c|c|}
\hline \multirow{2}{*}{$\begin{array}{l}\text { Jednostka } \\
\text { osadnicza }\end{array}$} & \multicolumn{2}{|c|}{ Babiogórski } & \multicolumn{2}{|c|}{ Gorczański } & \multicolumn{2}{|c|}{ Magurski } & \multicolumn{2}{|c|}{ Pieniński } & \multicolumn{2}{|c|}{ Tatrzański } \\
\hline & 1. $0 . *$ & $\%$ & 1. $0 . *$ & $\%$ & $0 . *$ & $\%$ & $0 . *$ & $\%$ & 1. $0 . *$ & $\%$ \\
\hline 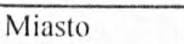 & 223 & -5 & 74 & 0 & 220 & 020 & 424 & 055 & 1671 & 93,77 \\
\hline & 2 & & 19 & & 18 & & 19 & 4 , & 76 & 4,26 \\
\hline Cudz & 3 & 1,2 & 2 & 0,68 & 1 & 0,42 & 1 & 0,23 & 35 & 1,96 \\
\hline gólem & 249 & 100,00 & 295 & 100,00 & 239 & 100,00 & 444 & 100,00 & 1782 & 100,00 \\
\hline
\end{tabular}

I. o. *- liczba osób.

Źr ó d l o: Opracowanie własne na podstawie badań ankietowych.

Wyniki badań dotyczących pochodzenia turystów, w zależności od wielkości miast, prezentuje tab. VII i rys. 5. Już wstępna analiza pozwala na stwierdzenie, że w miarę zmniejszania się wielkości miast, maleje także liczba osób z nich przyjeżdżających. W konsekwencji tego, najliczniej reprezentowane są wielkie aglomeracje miejskie, jak: Kraków, Łódź, Poznań, Warszawa, Wrocław, 
Ta bela VII

Turyści odwiedzający parki narodowe w Karpatach Zachodnich wg wielkości miast, z których pochodzą (1996 r.)

Les touristes visitant les parcs nationaux des Karpates d'Ouest selon les villes de leur origine territoriale 1996

\begin{tabular}{|c|r|r|r|r|r|r|r|r|r|r|}
\hline \multirow{2}{*}{$\begin{array}{c}\text { Wielkość } \\
\text { miast }\end{array}$} & \multicolumn{2}{|c|}{ Babiogórski } & \multicolumn{2}{c|}{ Gorczański } & \multicolumn{2}{c|}{ Magurski } & \multicolumn{2}{|c|}{ Pieniński } & \multicolumn{2}{c|}{ Tatrzański } \\
\cline { 2 - 10 } & 1. o.* & \multicolumn{1}{c|}{$\%$} & 1. o.* & $\%$ & 1. o.* & $\%$ & I. o.* & $\%$ & 1. o.* & $\%$ \\
\hline$<10$ tys. osób & 6 & 2,7 & 9 & 3,3 & 6 & 2,7 & 21 & 4,9 & 53 & 3,1 \\
$10001-25000$ & 23 & 10,3 & 20 & 7,3 & 13 & 5,9 & 42 & 9,9 & 153 & 9,2 \\
$25001-50000$ & 31 & 14,0 & 26 & 9,5 & 28 & 12,7 & 38 & 8,9 & 173 & 10,4 \\
$50001-100000$ & 27 & 12,1 & 28 & 10,2 & 16 & 7,3 & 55 & 13,0 & 167 & 10,0 \\
$100001-200000$ & 36 & 16,1 & 23 & 8,4 & 32 & 14,6 & 44 & 10,4 & 211 & 12,6 \\
$200001-500000$ & 49 & 22,0 & 36 & 13,1 & 36 & 16,3 & 87 & 20,6 & 321 & 19,2 \\
$>500001$ & 51 & 22,8 & 132 & 48,2 & 89 & 40,5 & 137 & 32,3 & 593 & 35,5 \\
\hline Ogółem & 223 & 100,0 & 274 & 100,0 & 220 & 100,0 & 424 & 100,0 & 1671 & 100,0 \\
\hline
\end{tabular}

l. o. *-liczba osób.

Ź r ó d l o: Opracowanie wlasne na podstawie badań ankietowych.

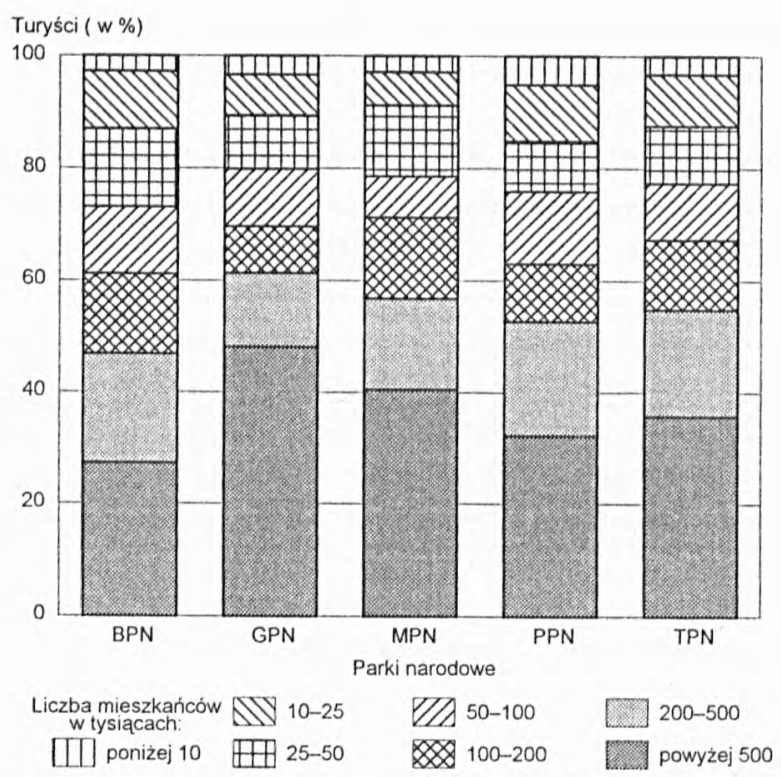

Rys. 5. Turyści parków narodowych w Karpatach Zachodnich wg wielkości miast, z których pochodzą (1996 r.)

Dessin 5. Les touristes visitant les parcs nationaux des Karpates d'Ouest selon la grandeur des villes de leur origine territoriale (1996) 

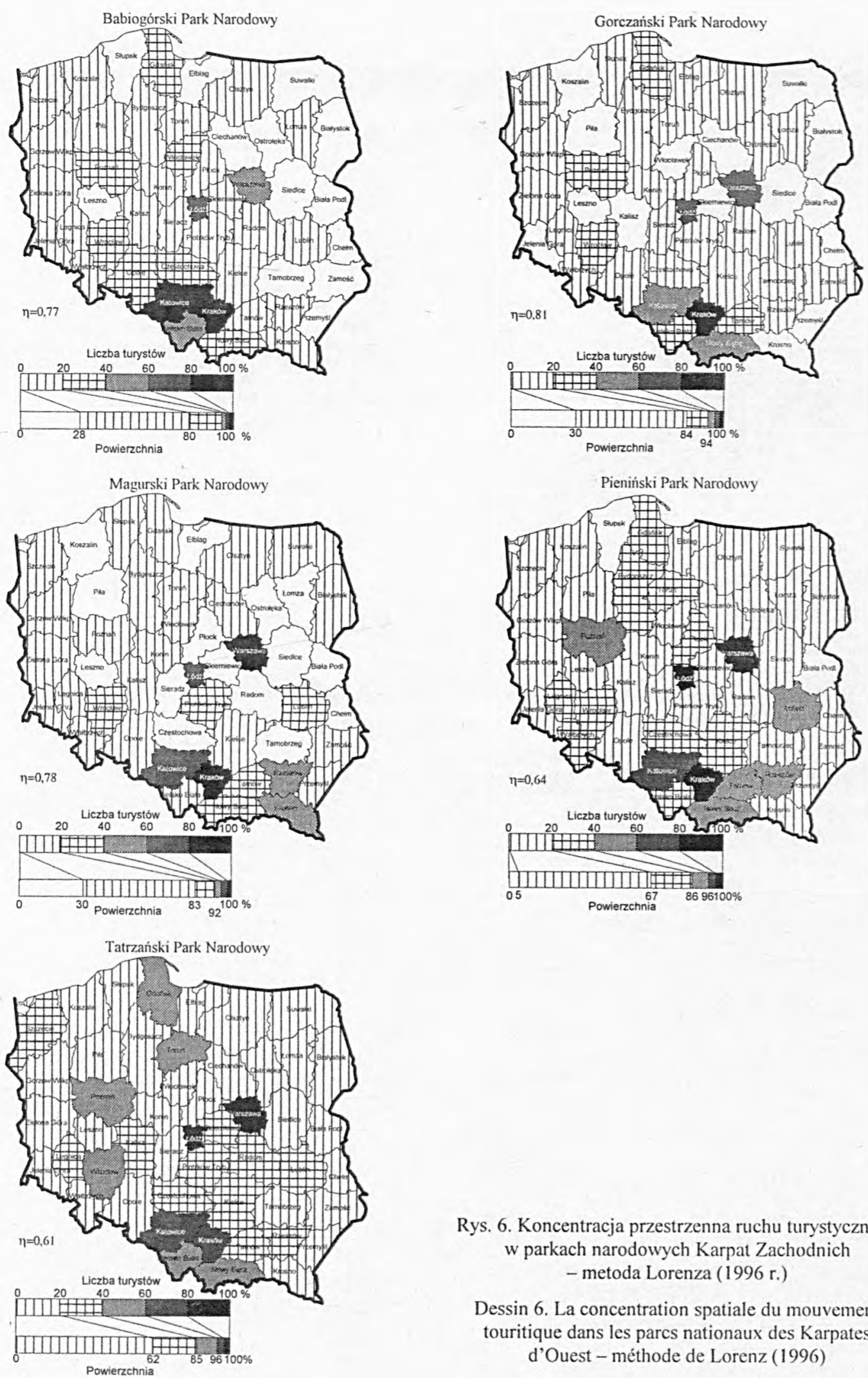

Rys. 6. Koncentracja przestrzenna ruchu turystycznego w parkach narodowych Karpat Zachodnich - metoda Lorenza (1996 r.)

Dessin 6. La concentration spatiale du mouvement touritique dans les pares nationaux des Karpates d'Ouest - méthode de Lorenz (1996) 
liczące powyżej 500 tys. osób. W sumie, z miast tych przyjeżdża od ok. $23 \%$ turystów Babiogórskiego, 32-35\% Pienińskiego i Tatrzańskiego, do ok. 48\% Gorczańskiego Parku Narodowego. Mniej liczną, ale znacząca grupę tworzą osoby mieszkające w miastach liczących 200-500 tys. mieszkańców (np. Bydgoszcz, Częstochowa, Gdańsk). Z miast tych pochodzi od ok. 13\% (Gorczański Park Narodowy) do ok. $20 \%$ (Pieniński Park Narodowy) turystów badanych parków. W sumie, z miast liczących powyżej 100 tys. mieszkańców pochodzi od ok. $61 \%$ turystów Babiogórskiego do ok. 71\% Magurskiego Parku Narodowego.

$\mathrm{Z}$ zaprezentowanych danych wynikają dwa podstawowe wnioski. Po pierwsze, liczba turystów przyjeżdżających $\mathrm{z}$ danego miasta jest proporcjonalna do jego wielkości. Po drugie, wielkość miasta determinuje potrzebę wyjazdu turystycznego ( $m a$ to związek $\mathrm{z}$ niedogodnościami życia w mieście, np. dużą gęstością zaludnienia, hałasem, zanieczyszczeniami itd.).

\subsection{ZASIĘG PRZESTRZENNY}

Miejscowość, województwo czy region, z którego przyjeżdżają odwiedzajacy, ma szczególne znaczenie dla określenia zasięgu przestrzennego oddziaływania konkretnego obszaru (rangi).

W celu zilustrowania przestrzennego zróżnicowania ruchu turystycznego w parkach narodowych Karpat Zachodnich wykonano mapy koncentracji przestrzennej (rys. 6) i wyliczono wartość współczynnika koncentracji (n). W odniesieniu do badanej grupy parków wspomniana wartość oscyluje w przedziale $n=0,62-0,81$. O średniej koncentracji, a więc w miarę równomiernym rozkładzie, można mówić w odniesieniu do Tatrzańskiego i Pienińskiego Parku Narodowego $(n=0,61 ; n=0,64)$. Na terenie pierwszego $\mathrm{z}$ nich ok. $20 \%$ turystów pochodzi tylko z dwóch województw, tzn.: łódzkiego i warszawskiego. Kolejne $20 \%$ to osoby z katowickiego i krakowskiego. W sumie ok. $40 \%$ turystów tego parku pochodzi z ok. $5 \%$ powierzchni kraju. Podobne prawidłowości dotycza drugiego parku.

O koncentracji przestrzennej można mówić w odniesieniu do pozostałych parków. W Babiogórskim Parku Narodowym $(n=0,77)$ turyści z woj. katowickiego, krakowskiego i łódzkiego stanowią ok. $40 \%$ odwiedzających; podobnie z bielskiego i warszawskiego. W sumie, $60 \%$ wszystkich odwiedzających pochodzi tylko z ok. $8 \%$ powierzchni Polski. W Magurskim Parku Narodowym $(n=0,78)$ turyści z woj. krakowskiego, warszawskiego, katowickiego, łódzkiego, krośnieńskiego i rzeszowskiego stanowią ok. $60 \%$ całego ruchu turystycznego, a powierzchnia zajęta przez te województwa zajmuje tylko $8 \%$ kraju. Z kolei w Gorczańskim Parku Narodowym $(n=0,81)$ dominują mieszkańcy województwa krakowskiego, łódzkiego, warszawskiego, a następnie katowickiego i nowosądeckiego. Stanowią oni ok. $60 \%$ wszystkich turystów. 
Uzupełnieniem powyższej charakterystyki jest wykres prezentujący koncentrację przestrzenną turystów wg stref odległości od poszczególnych parków. (tab. VIII, rys. 7). Strefy te wyznaczone zostały na podstawie 100-kilometrowych odcinków. W zależności od położenia stolicy województwa, było ono klasyfikowane do odpowiedniej grupy. Z rysunku wynika, że w dwóch parkach - Tatrzańskim i Pienińskim - dominująca grupa turystów pochodzi z obszarów położonych w odległości od 100 do $200 \mathrm{~km}$ oraz od 300 do $400 \mathrm{~km}$. W obu parkach zauważa się także dość duży udział turystów z województw położonych w strefie od 400 do $500 \mathrm{~km}, \mathrm{z}$ których przybyło do każdego z parków ok. 14-16\% odwiedzających. Porównując wzajemne relacje pomiędzy poszczególnymi strefami, wyrażone liczbą turystów, można stwierdzić, że omawiane dwa parki sa atrakcyjne czy też popularne nie tylko wśród mieszkańców najbliższych województw, ale stanowią atrakcyjny cel także dla osób mieszkających dość daleko i daleko od parków (ok. 60-70\% turystów z obszarów oddalonych o ok. 200 km).

Tabela VIII

Koncentracja przestrzenna ruchu turystycznego w parkach narodowych Karpat Zachodnich wg stref odległości (1996 r.)

La concentration spatiale du mouvement touristique dans les parcs nationaux des Karpates d'Ouest selon les zones l'éloignement 1996

\begin{tabular}{|c|c|c|c|c|c|c|c|c|c|c|}
\hline \multirow{2}{*}{$\begin{array}{c}\text { Strefy odleg- } \\
\text { lości }(\mathrm{km})\end{array}$} & \multicolumn{2}{|c|}{ Babiogórski } & \multicolumn{2}{|c|}{ Gorczański } & \multicolumn{2}{|c|}{ Magurski } & \multicolumn{2}{|c|}{ Pieniński } & \multicolumn{2}{|c|}{ Tatrzański } \\
\hline & 1. o.* & $\%$ & 1. $0 . *$ & $\%$ & 1. o.* & $\%$ & 1. o.* & $\%$ & I. o.* & $\%$ \\
\hline$<100$ & 64 & 25,70 & 123 & 41,70 & 39 & 16,31 & 16 & 3,60 & 0 & 0,00 \\
\hline $101-200$ & 88 & 35,34 & 53 & 17,97 & 69 & 28,87 & 152 & 34,23 & 439 & 24,63 \\
\hline $201-300$ & 26 & 10,44 & 35 & 11,86 & 50 & 20,92 & 41 & 9,23 & 214 & 12,00 \\
\hline $301-400$ & 36 & 14,47 & 38 & 12,88 & 45 & 18,82 & 117 & 26,35 & 578 & 32,44 \\
\hline $401-500$ & 13 & 5,22 & 20 & 6,77 & 14 & 5,85 & 71 & 15,99 & 250 & 14,03 \\
\hline $501-600$ & 8 & 3,21 & 5 & 1,70 & 11 & 4,60 & 25 & 5,63 & 96 & 5,39 \\
\hline $601-700$ & 11 & 4,42 & 19 & 6,44 & 8 & 3,34 & 11 & 2,49 & 146 & 8,20 \\
\hline$>701$ & 0 & 0,00 & 0 & 0,00 & 2 & 0,87 & 10 & 2,25 & 24 & 1,35 \\
\hline Cudzozies & 3 & 1,20 & 2 & 0,68 & 1 & 0,42 & 1 & 0,23 & 35 & 1,96 \\
\hline Ogółem & 249 & 100,00 & 295 & 100,00 & 239 & 100,00 & 444 & 100,00 & 1782 & 100,00 \\
\hline
\end{tabular}

I. o. * - liczba osób.

Ź r ó d lo: Opracowanie wlasne na podstawie badań ankietowych.

Zupełnie innych wniosków dostarcza analiza wyników otrzymanych dla Babiogórskiego czy Gorczańskiego Parku Narodowego. W obu przypadkach turyści pochodzący z tzw. najbliższej okolicy, czyli do $200 \mathrm{~km}$ od parku, stanowią aż ok. $60 \%$ ogółu odwiedzających. Warto podkreślić jednak, że o ile w parku na Babiej Górze najwięcej odnotowuje się turystów z województw położonych w strefie 100-200 km (ok. 35\%), przede wszystkim katowickiego, to w Gorcach 
zdecydowaną przewagę liczebną mają osoby mieszkające w bezpośrednim sąsiedztwie parku (do $100 \mathrm{~km}$ ), a więc mieszkańcy woj. krakowskiego, nowosądeckiego, bielskiego (ok. 42\%). Zaprezentowane wyniki świadczą o tym, że wymienione parki są bardziej atrakcyjne dla mieszkańców ościennych województw niż dla turystów z pozostałych części kraju, a ich rangę można określić jako regionalną.

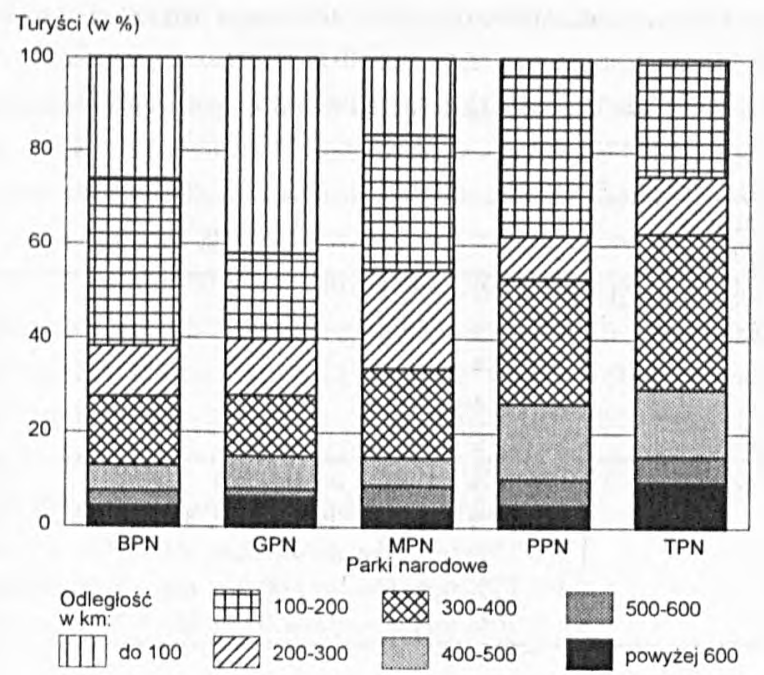

Rys. 7. Koncentracja przestrzenna ruchu turystycznego w parkach narodowych w Karpatach Zachodnich wg stref odległości (1996 r.)

Dessin 7. La concentration spatiale du mouvement touristique dans les parcs nationaux des Karpates selon les zones de l'éloignement (1996)

Podobne znaczenie należy przypisać też Magurskiemu Parkowi Narodowemu; odwiedzają go przede wszystkim osoby zamieszkujące tereny bezpośrednio przylegające do parku oraz z nim sąsiadujące.

W celu precyzyjnego określenia zasięgu przestrzennego ruchu turystycznego dla parków narodowych w Karpatach Zachodnich zastosowano dwa parametry:

- wartość współczynnika koncentracji $(n)$, oraz

- odleglość liniową miejsca zamieszkania od parku.

Kryteria określenia rangi parku przedstawione zostały w tab. IX. Zaklasyfikowanie do przedziału od jednego do pięciu oznaczało odpowiednio rangę: lokalną, regionalną, ponadregionalną, krajową i międzynarodową.

Niektóre obszary w zakresie przyjętych kryteriów klasyfikowały się w dwóch różnych grupach (Babiogórski, Magurski, Tatrzański). W takim przypadku o os- 
tatecznym zasięgu decydowała wielkość ruchu turystycznego. Zgodnie z przyjętymi zasadami postanowiono uznać zasięg badanych obszarów za:

- regionalny: Babiogórski, Gorczański, Magurski Park Narodowy,

- krajowy: Pieniński, Tatrzański Park Narodowy.

Tabela IX

Mierniki i kryteria wyznaczenia zasięgu przestrzennego parków narodowych w Karpatach Zachodnich (1996 r.)

Les étalons et les criterès de la détermination de l'étendue spatiale des nationaux dans les Karpates d'Ouest 1996

\begin{tabular}{|l|l|l|}
\hline \multicolumn{1}{|c|}{$\begin{array}{c}\text { Mierniki zasięgu } \\
\text { przestrzennego }\end{array}$} & \multicolumn{1}{|c|}{ Kryteria } & Parki \\
\hline $\begin{array}{l}\text { Wspólezynnik koncentracji } \\
\text { przestrzennej ruchu } \\
\text { turystycznego }\end{array}$ & $1-1,00-0,90$ & GPN \\
& $2-0,89-0,80$ & BPN, MPN \\
& $3-0,79-0,65$ & PPN, TPN \\
& $4-0,64-0,50$ & \\
\hline Odleglość liniowa od parku & $5-0,49-0,00$ & \\
& $2>50 \%$ turystów do $100 \mathrm{~km}$ \\
& $3>75 \%$ turystów do $200 \mathrm{~km}$, ale $>25 \%$ do $100 \mathrm{~km}$ & BPN, GPN \\
& $4>75 \%$ turystów do $400 \mathrm{~km}$, ale $<50 \% \mathrm{~km}$, ale $<75 \%$ do $200 \mathrm{~km}$ & MPN \\
& $5>90 \%$ km & PPN \\
&
\end{tabular}

Ż ró d to: Opracowanie własne.

Celowe wydaje się przypomnienie, że badaniami nie zostali objęci cudzoziemcy, stąd też żaden z parków nie mógł uzyskać rangi międzynarodowej. Prawdopodobne wydaje się jednak, że takim zasięgiem oddziaływania mógłby charakteryzować się zarówno Tatrzański, jak i Pieniński Park Narodowy. W tym przypadku więc, wskazane jest zasygnalizowanie co najmniej krajowego ich zasięgu.

\subsection{CZĘTOTLIWOŚĆ PRZYJAZDÓW, DŁUGOŚĆ POBYTU, CELE PRZYJAZDÓW}

Jednym z podstawowych sposobów potwierdzenia popularności, atrakcyjności, a w konsekwencji też znaczenia obszaru, jest ustalenie liczby kolejnych wizyt złożonych przez tych samych turystów. Pośrednio, element ten świadczy również o stopniu znajomości terenu i ,przywiązaniu” do niego.

$\mathrm{Na}$ terenie badanych parków autorka wydzieliła trzy następujące grupy turystów, są to: 
1) osoby, które odwiedziły określony park po raz pierwszy i dopiero rozpoczynają jego poznawanie; jest to grupa „odkrywających" park;

2) turyści, którzy mają już za sobą pierwszy kontakt z parkiem, a ich kolejne wizyty zmierzają do jego bliższego poznania; są to osoby penetrujące park; do grupy tej zaliczono turystów, którzy odwiedzili park więcej niż raz, ale nie więcej niż dziesięć razy;

3) odwiedzający, którzy mają za sobą dowolną liczbę wizyt w parku, ale nie mniej niż dziesięć; są to osoby zasymilowane z parkiem.

Ciekawych wniosków dostarcza analiza porównawcza omawianego zagadnienia dla poszczególnych parków narodowych (tab. X, rys. 8). Na jej podstawie stwierdzić można, że z wyjątkiem Magurskiego Parku Narodowego, na pozostałych terenach przeważają turyści, którzy są tu po raz kolejny. Ich udział jest oczywiście inny dla każdego parku, a wartości wahają się od ok. 82,5\% w Tatrzańskim do ok. 57\% w Pienińskim Parku Narodowym. Wśród osób powracających do parku szczególne znaczenie mają te, które są na jego obszarze stałymi bywalcami (powyżej 10 wizyt) i tworzą grupę klientów, przyjeżdżających choćby tylko z przyzwyczajenia czy tradycji. Najliczniej jest ona reprezentowana w Tatrzańskim (ok. 19,5\%) i Gorczańskim Parku Narodowym (ok. 16\%), najmniej licznie w Pienińskim Parku Narodowym (3\%).

T a bela $X$

Liczba wizyt złożonych przez turystów w parkach narodowych Karpat Zachodnich (1996 r.)

Le nombre de visites faites par les touristes dans parcs nationaux des Karpates d'Ouest (1996)

\begin{tabular}{|c|c|c|c|c|c|c|c|c|c|c|}
\hline \multirow{2}{*}{$\begin{array}{c}\text { Liczba } \\
\text { wizyt }\end{array}$} & \multicolumn{2}{|c|}{ Babiogórski } & \multicolumn{2}{|c|}{ Gorczański } & \multicolumn{2}{|c|}{ Magurski } & \multicolumn{2}{|c|}{ Pieniński } & \multicolumn{2}{|c|}{ Tatrzański } \\
\hline & 1. $0 . *$ & $\%$ & 1. o.* & $\%$ & 1. $0 . *$ & $\%$ & 1. o. ${ }^{*}$ & $\%$ & 1. $0 . *$ & $\%$ \\
\hline 1 & 92 & 36,95 & 88 & 29,83 & 119 & 49,8 & 192 & 43,24 & 313 & 17,56 \\
\hline $2-3$ & 82 & 32,94 & 78 & 26,44 & 55 & 23,01 & 173 & 38,96 & 455 & 25,53 \\
\hline $4-10$ & 59 & 23,69 & 82 & 27,80 & 48 & 20,08 & 65 & 14,65 & 667 & 37,43 \\
\hline $11-25$ & 9 & 3,61 & 29 & 9,83 & 17 & 7,11 & 12 & 2,70 & 213 & 11,95 \\
\hline$>25$ & 7 & 2,81 & 18 & 6,10 & 0 & 0,00 & 2 & 0,45 & 134 & 7,53 \\
\hline Ogólem & 249 & 100,00 & 295 & 100,00 & 239 & 100,00 & 444 & 100,00 & 1782 & 100,00 \\
\hline
\end{tabular}

1. o. * - liczba osób.

Ź r ó d l o: Opracowanie wlasne na podstawie badań ankietowych.

Do określenia znaczenia turystyki w parku, a także w pewnym stopniu poziomu jej rozwoju ważny jest nie tylko udział poszczególnych grup, ale także relacje, jakie pomiędzy nimi zachodza. Potwierdzenia tego faktu i jednocześnie poszukiwania modelowego przykładu należy rozpocząc od Tatrzańskiego Parku Narodowego. Udział poszczególnych grup w ogólnym ruchu turystycznym na 
tym obszarze świadczy, zdaniem autorki, o ugruntowanej i stabilnej pozycji turystycznej tego parku. Składają się na nią zarówno wysoki udział tzw. „turystów penetrujących" (ok. 60\%), jak i zrównoważony odsetek „turystów odkrywających" i ,zasymilowanych" z parkiem (po ok. 20\%). Inaczej przedstawia się sytuacja w odniesieniu do Magurskiego Parku Narodowego; ok. 50\% odwiedzających to osoby będące tu po raz pierwszy, brak natomiast wśród ankietowanych turystów osób, które przebywały na tym terenie więcej niż 25 razy, a więc kategorii „zasymilowanych” z parkiem. Tendencje te potwierdzają młody wiek parku i świadczyć mogą o wstępnej fazie jego turystycznego rozwoju. Parkami będącymi na etapie pośrednim, pomiędzy dwoma wymienionymi, są pozostałe trzy obszary. Charakteryzuje je duży udział osób przebywających na tym terenie pierwszy raz (od ok. 30\% w Gorczańskim do ok. 43\% w Pienińskim Parku Narodowym) i ok. $55 \%$ udział turystów penetrujących.

Osobnym zagadnieniem analizowanym przy okazji charakterystyki ruchu turystycznego jest długość pobytu. Na badanym terenie została ona określona na podstawie deklarowanej przez turystów liczby dni, które zamierzali spędzić na jego obszarze. Oczywiście, wielkość ta uzależniona jest od kilku elementów,

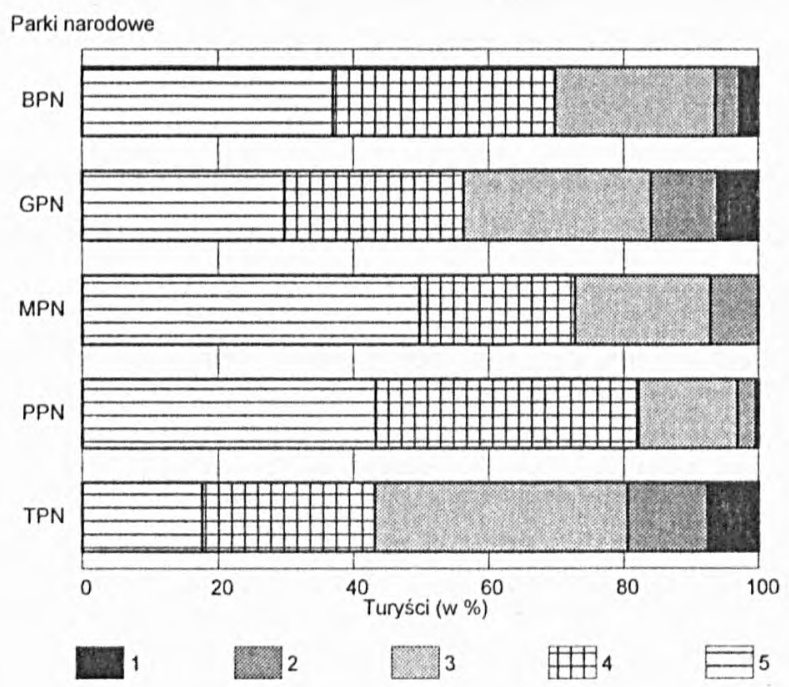

Rys. 8. Liczba wizyt zlożonych przez turystów w parkach narodowych Karpat Zachodnich (1996 r.)

1-powyżej 25 wizyt, 2 - 11-25 wizyt, 3-4-10 wizyt, 4-2-3 wizyty, 5-1 wizyta

Dessin 8. Le nombre de visites rendues par les touristes dans les pares nationaux des Karpates d'Ouest 1996

1 -plus de 25 visites, $2-11-25$ visites, $3-4-10$ visites, $4-2-3$ visites, $5-1$ visite 
m. in. wielkości parku, jego walorów, zagospodarowania czy choćby czasu, jakim dysponują odwiedzający park. Wyniki badań przedstawione są $w$ tab. XI i na rys. 9 . Wynika z nich, że krótkie pobyty sa charakterystyczne dla osób odwiedzających Babiogórski Park Narodowy: ok. $46 \%$ turystów przebywa tu tylko jeden dzień, a ok. $48 \%$ dwa lub trzy dni. Omawiany obszar jest najczęściej punktem docelowym kilkugodzinnych wycieczek odbywanych przez wypoczywających w pobliżu turystów (np. w Zawoji, Rabce, Zakopanem), lub punktem etapowym dla wędrujących szlakami beskidzkimi. Ponadto, jest to teren atrakcyjny dla mieszkańców sąsiadujących z parkiem województw (bielskie, katowickiego,

T a be I a XI

Dlugość pobytu turystów na terenie parków narodowych w Karpatach Zachodnich (1996 r.)

La longueur de séjour des touristes sur la terrain des pares nationaux dans les Karpates d'Ouest 1996

\begin{tabular}{|c|c|c|c|c|c|c|c|c|c|c|}
\hline \multirow{2}{*}{$\begin{array}{l}\text { Dlugość } \\
\text { pobytu }\end{array}$} & \multicolumn{2}{|c|}{ Babiogórski } & \multicolumn{2}{|c|}{ Gorczański } & \multicolumn{2}{|c|}{ Magurski } & \multicolumn{2}{|c|}{ Pieniński } & \multicolumn{2}{|c|}{ Tatrzański } \\
\hline & I. o.* & $\%$ & 1.0.* & $\%$ & I. $0 . *$ & $\%$ & 1. $0 . *$ & $\%$ & I. $0 . *$ & $\%$ \\
\hline 1 dzień & 114 & 45,78 & 98 & 33,22 & 29 & 12,13 & 56 & 12,61 & 112 & 6,29 \\
\hline $2-3$ dni & 120 & 48,19 & 106 & 35,93 & 99 & 41,42 & 127 & 28,60 & 218 & 12,23 \\
\hline I tydzień & 13 & 5,22 & 87 & 29,49 & 90 & 37,66 & 202 & 45,50 & 913 & 51,23 \\
\hline 2-3 tygodnie & 0 & 0.00 & 4 & 1,36 & 20 & 8,37 & 57 & 12,84 & 512 & 28,73 \\
\hline Dlużej & 2 & 0,80 & 0 & 0,00 & 1 & 0,42 & 2 & 0,45 & 27 & 1,52 \\
\hline Ogółem & 249 & 100,00 & 295 & 100,00 & 239 & 100,00 & 444 & 100,00 & 1782 & 100,00 \\
\hline Śred. długość & 2,15 & $x$ & 3,05 & $x$ & 4,55 & $x$ & 5,32 & $x$ & 7,73 & $\mathrm{x}$ \\
\hline
\end{tabular}

1. o. * - liczba osób.

Ź ró d ło: Opracowanie własne na podstawie badań ankietowych.

krakowskiego), którzy ze względu na bliskość i łatwy dostęp, właśnie tutaj organizują sobie krótkie wypady w czasie letnich weekendów. Niewielki odsetek osób przebywających na jego terenie tydzień (ok. 5\%) i dłużej potwierdza, że jest to rejon w całości osiaggalny przez turystów w ciągu zaledwie kilku dni i jeśli stanowi bezpośredni i jedyny cel wycieczki, to tylko dla odwiedzających mieszkających w niedalekiej od niego odległości. Znaczący udział osób (ok. $33 \%$ ) przebywających tylko jeden dzień w parku notuje się także na obszarze Gorczańskiego Parku Narodowego. Są to najczęściej osoby wypoczywające w niedalekiej odległości od pasma Gorców, dla których głównym celem jest jego najwyższy szczyt - Turbacz. Równie liczna jest grupa turystów (ok. 36\%) goszcząca w parku dwa lub trzy dni. Są to przeważnie osoby wędrujące głównym (czerwonym) szlakiem beskidzkim na odcinku Rabka-Krościenko, nocujące w jednym z obiektów na terenie parku lub przy jego granicy. Trzecią pod wzglę- 
dem liczebności grupę (ok. 29,5\%) stanowią turyści przebywający w tym parku około jednego tygodnia. Są to najczęściej osoby, które wypoczywają w zakładowych ośrodkach lub kwaterach prywatnych zlokalizowanych w miejscowościach położonych u podnóża pasma Gorców (Koninki, Niedźwiedź, Ochotnica, Poręba Wielka itd.), a wędrówki górskie traktują jako formę spędzania wolnego czasu.

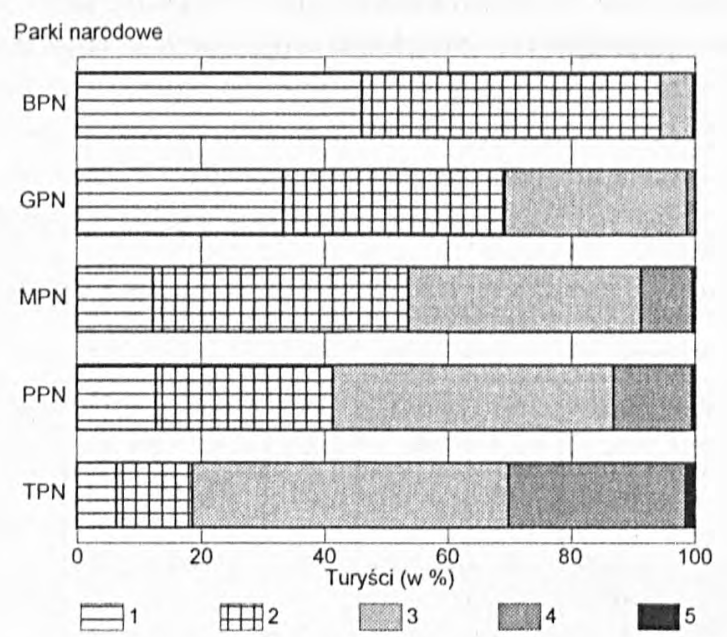

Rys. 9. Dlugość pobytu turystów w parkach narodowych Karpat Zachodnich (1996 r.)

$1-1$ dzień, 2-2-3 dni, 3-1 tydzień, 4-2-3 tygodnie, 5- dłużej niż 3 tygodnie

Dessin 9. La longueur du séjour des touristes dans les parcs nationaux des Karpates d'Ouest 1996 $1-1$ jour, $2-2-3$ jours, $3-1$ semaine, $4-2-3$ semaines, 5 - séjour plus long que 3 semaines

W pozostałych trzech parkach czas pobytu wydłuża się i osiagga największe wartości w Tatrzańskim Parku Narodowym. Fakt, że krótkie pobyty (1-3 dni) stanowią tylko ok. $18,5 \%$ w całości ruchu turystycznego świadczy o tym, że jest to teren atrakcyjny na tyle, że nie „opłaca się” tu przyjeżdżać na krócej niż co najmniej siedem dni (ok. 51\%). Potwierdzeniem tego może być także ok. 29\% udział przyjazdów dwu- lub trzytygodniowych. Istotne w tym przypadku wydaje się ponadto przypomnienie, że turyści na obszarze Tatrzańskiego Parku Narodowego pochodzą z obszaru całej Polski, a dość duży ich udział przypada na tereny znacznie oddalone od parku. Długa podróż do parku musi być więc zrekompensowana przez odpowiednio długi pobyt na miejscu. Ta sama uwaga dotyczyć może Pienińskiego Parku Narodowego, aczkolwiek konieczne jest w tym miejscu zasygnalizowanie, że ankietowanie turystów miało miejsce na szlakach ich turystycznych wędrówek, a zatem nie objęło osób, które przyjechały do Pienińskiego Parku Narodowego w celu wzięcia udziału w spływie 
Dunajcem. Przeprowadzone przez A. Z i a r k o w s k ą (1992) badania, dotyczące tylko tej atrakcji turystycznej Pienin, potwierdzaja przypuszczenia o dominacji na tym terenie pobytów krótkich. $Z$ badań tych wynika, że blisko $81 \%$ turystów korzystających ze spływu przebywa w Pieninach 1-3 dni, ok. 10\%tydzień, a pozostała, niewielka liczba - dwa tygodnie. Przedstawiony materiał pozwala zweryfikować wyniki ankiet i uznać ten park za obszar krótkiego lub co najwyżej średnio dhugiego pobytu.

Ostatni z karpackich parków narodowych - Magurski - charakteryzuje w miarę równomierny rozkład pobytów krótkich (1-3 dni) i długich (powyżej tygodnia). Wynika to $\mathrm{z}$ faktu, że park ten jest jednym $\mathrm{z}$ etapów wycieczek górskich odbywanych pomiędzy Bieszczadami a Beskidem Sądeckim, a ponadto terenem odwiedzanym ,samym w sobie” bądź przez wczasowiczów odpoczywających w Krempnej, Foluszu czy Wapiennym, bądź przez turystów przyjeżdżających w celu poznania regionu.

Potwierdzeniem znaczenia parku dla turystów, a także w pewnym stopniu wyjaśnieniem długości pobytu na jego terenie, jest analiza celów przyjazdu (tab. XII, rys. 10). Mając do wyboru wiele możliwości (lista celów sporządzona przez autorkę), największa liczba respondentów podkreślała, że wizyta w parku jest bezpośrednim celem ich przyjazdu. Wśród badanej grupy cel ten miał największe znaczenie dla turystów Tatrzańskiego (ok. 77\%) i Pienińskiego Parku Narodowego (ok. 65\%). Dużo mniejszą rolę, choć także ważna, odgrywał wybór parku jako cel wizyty dla turystów przebywających na obszarze pozostałych parków; Magurski był celem dla ok. 34\% turystów, a Gorczański dla ok. 44\% odwiedzających go.

Dla dużej grupy odwiedzających wycieczka do parku odbyła się głównie przy okazji wypoczynku w pobliżu. Dotyczy to ok. $24 \%$ przebywających na terenie Gorczańskiego Parku Narodowego, ok. 22\% - na obszarze Magurskiego i ok. $20 \%$ - Babiogórskiego Parku Narodowego. Pośrednio z wypoczynkiem związany jest także pobyt w sanatorium. Wprawdzie udział kuracjuszy w ogólnym ruchu turystycznym na obszarze karpackich parków jest niewielki, ale zaznacza się jednak na terenie Babiogórskiego, Gorczańskiego, Pienińskiego i Tatrzańskiego Parku Narodowego. W sąsiedztwie tych parków znajdują się uzdrowiska: Rabka, Szczawnica, Zakopane, z których kuracjusze odwiedzają wymienione parki.

Omawiany teren jest także odwiedzany w ramach dłuższego wyjazdu, którego etapami są poszczególne pasma górskie. Etapowym obszarem w dłuższym programie turystycznym jest przede wszystkim Magurski Park Narodowy, który odwiedza w ten sposób ok. $38 \%$ turystów wędrujących najczęściej pomiędzy Beskidem Sądeckim a Bieszczadami. Wysoki udział turystów tej grupy notuje się także na terenie Babiogórskiego Parku Narodowego (ok. 31\%), odwiedzanego wraz z Beskidem Żywieckim, Śląskim czy Gorcami. Ten model turystyki popularny jest również w Gorczańskim Parku Narodowym (ok. 23\%), który 
Tabela XII

Cele podróży turystów do parków narodorvych w Karpatach Zachodnich (1996r.)

Les buts de voyage des touristes dans les parcs nationaux des Karpates d'Ouest 1996

\begin{tabular}{|c|c|c|c|c|c|c|c|c|c|c|}
\hline \multirow[b]{2}{*}{ Cel podróży } & \multicolumn{2}{|c|}{ Babiogórski } & \multicolumn{2}{|c|}{ Gorczański } & \multicolumn{2}{|c|}{ Magurski } & \multicolumn{2}{|c|}{ Pieniński } & \multicolumn{2}{|c|}{ Tatrzański } \\
\hline & $\begin{array}{c}\text { Liczba } \\
\text { osób }\end{array}$ & $\%$ & $\begin{array}{c}\text { Liczba } \\
\text { osób }\end{array}$ & $\%$ & $\begin{array}{c}\text { Liczba } \\
\text { osób }\end{array}$ & $\%$ & $\begin{array}{c}\text { Liczba } \\
\text { osób }\end{array}$ & $\%$ & $\begin{array}{c}\text { Liczba } \\
\text { osób }\end{array}$ & $\%$ \\
\hline Wizyta w parku & 97 & 38,97 & 129 & 43,73 & 82 & 34,31 & 290 & 65,31 & 1368 & 76,77 \\
\hline Wypoczynek w pobliżu & 49 & 19,68 & 72 & 24,41 & 53 & 22,18 & 69 & 15,55 & 276 & 15,49 \\
\hline Pobyt w uzdrowisku & 3 & 1,20 & 4 & 1,36 & 0 & 0,00 & 4 & 0,90 & 11 & 0,62 \\
\hline Wizyta u rodziny & 16 & 6,42 & 11 & 3,73 & 13 & 5,43 & 9 & 2,03 & 41 & 2,30 \\
\hline Służbowo & 3 & 1,20 & 1 & 0,34 & 0 & 0,00 & 1 & 0,22 & 9 & 0,50 \\
\hline Tranzyt & 3 & 1,20 & 0 & 0,00 & 1 & 0,42 & 0 & 0,00 & 3 & 0,17 \\
\hline Etap wycieczki & 77 & 30,92 & 69 & 23,38 & 90 & 37,66 & 71 & 15,99 & 63 & 3,53 \\
\hline Inne & 1 & 0,41 & 9 & 3,05 & 0 & 0,00 & 0 & 0,00 & 11 & 0.62 \\
\hline Ogółem & 249 & 100,00 & 295 & 100,00 & 239 & 100,00 & 444 & 100,00 & 1782 & 100,00 \\
\hline
\end{tabular}

Ź r ó d ło: Opracowanie wlasne na podstawie badań ankietowych. 
przyjmuje turystów wędrujących $\mathrm{m}$. in. na trasie Krościenko-Lubań-Turbacz-Rabka. Etapem podróży jest także Pieniński Park Narodowy (dla ok. 16\% turystów), wybierany do poznania wraz z Tatrami lub Gorcami.

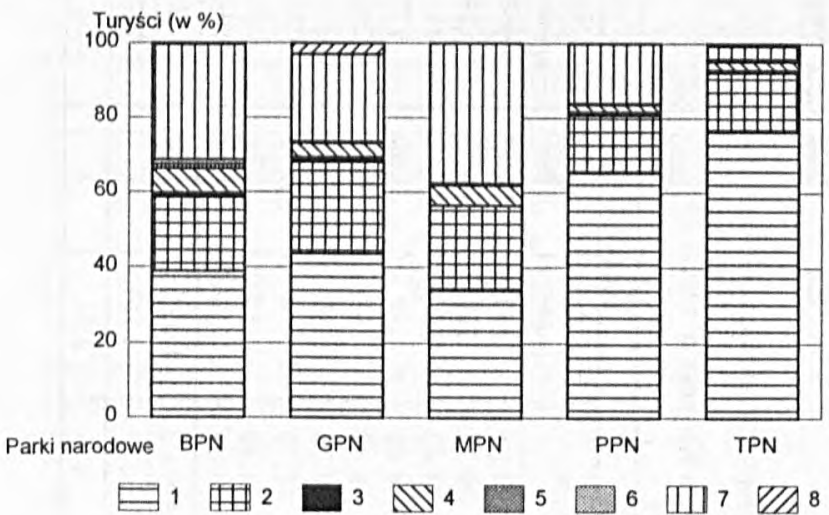

Rys. 10. Przyjazdy turystów do parków narodowych w Karpatach Zachodnich wg celów podróży (1996 r.)

1 - wizyta w parku, 2 - wypoczynek w pobliżu, 3 - pobyt w sanatorium, 4 - wizyta u rodziny, 5 - pobyt slużbowy, 6 - tranzyt, 7 -jeden z etapów, 8 -inne

Dessin 10. Les arrivées des touristes dans les parcs nationaux des Karpates d'Ouest selon les buts de voyage (1999)

1 - visite dans un parc, 2 - repos à proximité du parc, 3 - séjour au sanatorium, 4 - visite de famille, 5 - voyage de service, 6 - transit, 7 - une des étapes, 8 - autres

Czynnikami skłaniającymi do wizyt w wymienionych parkach narodowych są ponadto pobyty u rodziny, wyjazdy służbowe, tranzytowe przejazdy oraz inne powody, $\mathrm{m}$. in. religijne w przypadku Gorczańskiego Parku Narodowego (pielgrzymki). Powody te odgrywają jednak dużo mniejszą rolę w stosunku do wymienionych wcześniej.

\subsection{MOTYWY PRZYBYCIA}

Zdaniem K. Prze c ła w s k i e g o (1996) turystyka jest przede wszystkim zachowaniem człowieka, a jednym z czynników determinujących to zachowanie są motywy turystycznego wyjazdu.

Z przeprowadzonych badań wynika, że największe znaczenie w przyjazdach do karpackich parków narodowych miały trzy motywy. Są nimi: przyroda, poznanie i potrzeba zmiany miejsca, które razem, w zależności od parku, stanowiły od ok. $63 \%$ (Gorczański) do ok. 82\% (Pieniński) odpowiedzi (tab. XIII, rys. 11). 
Motywy przyjazdu turystów do parków narodowych w Karpatach Zachodnich (1996 r.)

Les motifs des arrivées des touristes dans les pares nationaux des Karpates d' Ouest 1996

\begin{tabular}{|c|c|c|c|c|c|c|c|c|c|c|}
\hline \multirow[b]{2}{*}{ Motyw } & \multicolumn{2}{|c|}{ Babiogórski } & \multicolumn{2}{|c|}{ Gorczański } & \multicolumn{2}{|c|}{ Magurski } & \multicolumn{2}{|c|}{ Pieniński } & \multicolumn{2}{|c|}{ Tatrzański } \\
\hline & $\begin{array}{c}\text { Liczba } \\
\text { osób }\end{array}$ & $\%$ & $\begin{array}{c}\text { Liczba } \\
\text { osób }\end{array}$ & $\%$ & $\begin{array}{c}\text { Liczba } \\
\text { osób }\end{array}$ & $\%$ & $\begin{array}{c}\text { Liczba } \\
\text { osób }\end{array}$ & $\%$ & $\begin{array}{c}\text { Liczba } \\
\text { osób }\end{array}$ & $\%$ \\
\hline Poznanie & 123 & 21,96 & 135 & 17,60 & 124 & 22,35 & 300 & 28,99 & 968 & 23,44 \\
\hline Przyroda & 153 & 27,32 & 211 & 27,51 & 163 & 29.37 & 329 & 31,79 & 1344 & 32,55 \\
\hline Zmiana środowiska & 115 & 20,53 & 137 & 17,86 & 130 & 23,42 & 223 & 21,55 & 861 & 20,85 \\
\hline Przyzwyczajenia & 24 & 4,28 & 53 & 6,91 & 26 & 4,68 & 32 & 3,09 & 177 & 4,29 \\
\hline Towarzystivo & 51 & 9,12 & 55 & 7,17 & 47 & 8,47 & 37 & 3,57 & 208 & 5,04 \\
\hline Sport & 35 & 6,25 & 58 & 7,56 & 21 & 3,78 & 40 & 3,86 & 279 & 6,76 \\
\hline Bliskość zamieszkania & 24 & 4,28 & 25 & 3,26 & 15 & 2,70 & 4 & 0,39 & 39 & 0,94 \\
\hline Czasowy pobyt & 31 & 5,54 & 50 & 6,52 & 10 & 1,80 & 34 & 3,28 & 65 & 1,57 \\
\hline Inne & 4 & 0,72 & 43 & 5,61 & 19 & 3,42 & 36 & 3,48 & 188 & 4,56 \\
\hline Ogółem odpowiedzi & 560 & 100,00 & 767 & 100,00 & 555 & 100,00 & 1035 & 100,00 & 4129 & 100,00 \\
\hline Liczba osób & 249 & $\mathrm{x}$ & 295 & $\mathrm{x}$ & 239 & $\mathrm{x}$ & 444 & $x$ & 1782 & $\mathrm{x}$ \\
\hline Średnia liczba odp./1 os. & 2,25 & $x$ & 2,60 & $x$ & 2.32 & $x$ & 2,33 & $x$ & 2,32 & $\mathrm{x}$ \\
\hline
\end{tabular}

Ź r ó d ł o: Opracowanie własne na podstawie badań ankietowych. 


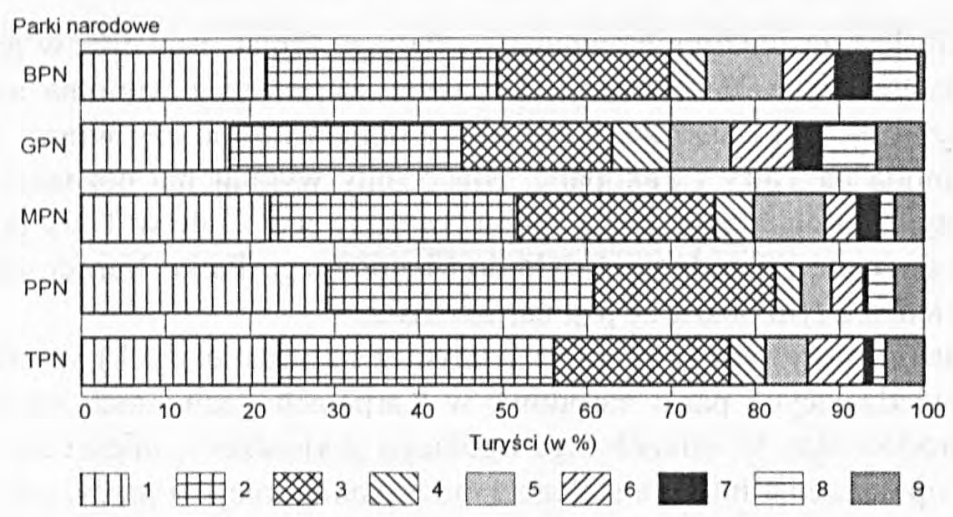

Rys. 11. Motywy przyjazdu do parków narodowych w Karpatach Zachodnich (1996 r.) 1 - poznanie, 2 - przyroda, 3 - zmiana środowiska, 4-przyzwyczajenia, 5-towarzystwo, 6 -sport, 7 -miejsce zamieszkania, 8-czasowy pobyt, 9 -inne

Dessin 11. Les motifs des arrivées dans les parcs nationaux des Karpates d'Ouest 1996 1 - désir de connaître, 2 - nature, 3 - changement du milieu, 4 - habitude, 5 - compagnie, 6 - sport. 7 - lieu d'habitation, 8 - séjour temporel, 9 - autres

Możliwość wyboru kilku elementów zadecydowała o tym, że większość turystów wskazywała na więcej niż jeden powód przyjazdu, o czym świadczy średnia liczba wybranych motywów przypadająca na osobę - od 2,25 (Babiogórski) do 2,6 (Gorczańskim) odpowiedzi. Spośród wymienionych trzech motywów największe znaczenie miała przyroda. Podano ją w ok. 27,5-32,5\% odpowiedzi. Pod hasłem tym kryje się przyroda w sensie ogólnym, a także chęć obcowania $\mathrm{z}$ nią, potrzeba bezpośredniego kontaktu z naturą, podziwiania jej piękna i doświadczania doznań estetycznych. Jako ważny, motyw ten podało ok. 74-75\% turystów przebywających na obszarze Pienińskiego i Tatrzańskiego Parku Narodowego oraz ok. 68-71,5\% gości Gorczańskiego i Magurskiego Parku Narodowego. Najniższa, ale także wysoką pozycję tego motywu (ok. 61,5\% odpowiedzi) odnotowano w wypowiedziach turystów odwiedzających Babiogórski Park Narodowy. Wymienienie przyrody, jako najważniejszego motywu przyjazdu do badanych obszarów, potwierdza znaczenie walorów przyrodniczych w podróżach turystycznych w ogóle.

Motywem, który po przyrodzie zajął następne miejsce, jest poznanie. Tę właśnie przyczynę pobytu w parku wymieniło ok. $29 \%$ turystów ankietowanych na obszarze Pienińskiego Parku narodowego, ok. 22-23\% na terenie Tatrzańskiego, Magurskiego i Babiogórskiego Parku Narodowego i ok. 17,5\% na obszarze Gorczańskiego Parku Narodowego. W przypadku pierwszego obszaru jest to zapewne konsekwencją wielu atrakcji oferowanych przez park (góry, spływ, zamek Czorsztyn), ale także wysokiego udziału pierwszych wizyt w parku, któ- 
rych celem jest zaspokojenie ciekawości na jego temat. Również w przypadku Tatrzańskiego Parku Narodowego, poznanie wiąże się z wieloma atrakcjami spotykanymi na tym obszarze, a ponadto $\mathrm{z}$ popularnością czy wręcz panująca ostatnio modą na Tatry i Zakopane. Nieco inny wymiar ma poznanie w przypadku przyjazdu do Magurskiego Parku Narodowego. O ile w Tatry przyjeżdża się, gdyż są znane i popularne, o tyle do Magurskiego Parku Narodowego - ponieważ wiedza o tym obszarze jest bardzo mała.

Kolejnym motywem (i zarazem jednym $\mathrm{z}$ najważniejszych) wymienionym przez odwiedzających parki narodowe w Karpatach Zachodnich jest potrzeba zmiany środowiska. W ramach tego ogólnego stwierdzenia mieści się zarówno potrzeba opuszczenia miejsca stałego zamieszkania, miejsca pracy, jak i zmiana otoczenia w zakresie kontaktów międzyludzkich. Motyw ten jest ważny także ze względów zdrowotnych, np. w odniesieniu do osób mieszkających w miastach, zwłaszcza dużych, w których zanieczyszczenie, hałas, nerwowy tryb życia wymuszają wręcz potrzebę zmiany środowiska. Znalazło to swoją egzemplifikację w ok. $18-23,5 \%$ odpowiedzi udzielonych przez turystów we wszystkich badanych parkach, z tym, że w Gorczańskim i Magurskim Parku Narodowym przewyższył motyw poznania. Świadczy to o tym, że pobyt na obszarze parków jest mniej atrakcyjny w sensie poznawczym, natomiast bardziej sprzyja usunięciu skutków fizycznego i psychicznego zmęczenia, co ma zapewne związek z małą liczbą turystów.

Pozostałe motywy odgrywają dużo mniejszą rolę i wymieniane są przez mniejszą liczbę turystów. Rzadziej są one motywem podstawowym, częściej pojawiają się obok innych. Ich znaczenie ujawnia się jako cecha indywidualna, charakteryzująca pobyty w poszczególnych parkach, np: przyzwyczajenie odgrywa najważniejszą rolę dla turystów z Gorczańskiego Parku Narodowego, towarzystwo dla turystów z Babiogórskiego, Magurskiego i Gorczańskiego Parku Narodowego, względy sportowe podnosiły osoby przebywające na obszarze Gorczańskiego, Tatrzańskiego i Babiogórskiego Parku Narodowego, bliskość miejsca zamieszkania przebywający w Babiogórskim, Gorczańskim i Magurskim Parku Narodowym, a bliskość tymczasowgo miejsca pobytu - w Gorczańskim, Babiogórskim i Pienińskim Parku Narodowym.

\section{TYPY FUNKCJONALNE PARKÓW NARODOWYCH}

$\mathrm{Na}$ podstawie zaprezentowanych analiz szczegółowych określono stopień rozwoju funkcji turystycznej i wyznaczono typy funkcjonalne badanych parków narodowych. Za najważniejsze mierniki w tej części pracy uznane zostały: wielkość ruchu turystycznego (A), zasięg oddziaływania parku wyrażony współczynnikiem koncentracji (B) i odległością liniową pomiędzy miejscem stałego 
T a bela XIV

Mierniki i kryteria wyznaczenia typów funkcjonalnych parków narodowych w Karpatach Zachodnich (1996 r.)

Les étalons et les critères de la détermination des types fonctionnels des parcs nationaux dans les Karpates d'Ouest 1996

\begin{tabular}{|c|c|c|}
\hline Miernik & Kryteria & Parki narodowe \\
\hline $\begin{array}{l}\text { A. Liczba turystów przypadająca } \\
\text { na } 1 \mathrm{~km} \text { szlaku turystycznego }\end{array}$ & $\begin{array}{l}1<1000 \text { osób } \\
2-1001-2500 \text { osób } \\
3-2501-5000 \text { osób } \\
4-5001-10000 \text { osób } \\
5>10000 \text { osób } \\
\end{array}$ & $\begin{array}{l}\text { MPN, GPN } \\
\text { BPN, } \\
\text { TPN, PPN }\end{array}$ \\
\hline $\begin{array}{l}\text { B. Współczynnik koncentracji } \\
\text { przestrzennej ruchu turystycz- } \\
\text { nego }\end{array}$ & \begin{tabular}{|l|}
$1-1,00-90,00$ \\
$2-0,89-0,80$ \\
$3-0,79-0,65$ \\
$4-0,64-0,50$ \\
$5-0,49-0,00$ \\
\end{tabular} & $\begin{array}{l}\text { GPN } \\
\text { BPN, MPN } \\
\text { PPN, TPN }\end{array}$ \\
\hline C. Odległość liniowa od parku & $\begin{array}{l}1>50 \% \text { turystów do } 100 \mathrm{~km} \\
2>50 \% \text { turystów do } 200 \mathrm{~km} \text {, ale }>25 \% \text { do } 100 \mathrm{~km} \\
3>75 \% \text { turystów do } 400 \mathrm{~km} \text {, ale }<50 \% \text { do } 200 \mathrm{~km} \\
4>75 \% \text { turystów do } 600 \mathrm{~km} \text {, ale }<75 \% \text { do } 400 \mathrm{~km} \\
5>90 \% \text { turystów do } 600 \mathrm{~km} \text {, ale }<75 \% \text { do } 400 \mathrm{~km}\end{array}$ & $\begin{array}{l}\text { BPN, GPN } \\
\text { MPN } \\
\text { PPN } \\
\text { TPN }\end{array}$ \\
\hline $\begin{array}{l}\text { D. Amplituda wielkości ruchu } \\
\text { turystycznego }\end{array}$ & $\begin{array}{l}1-80,01-100,00 \% \\
2-60,01-80,00 \% \\
3-40,01-60,00 \% \\
4-20,01-40,00 \% \\
5<20,00 \% \\
\end{array}$ & $\begin{array}{l}\text { MPN, PPN } \\
\text { BPN, GPN, TPN }\end{array}$ \\
\hline $\begin{array}{l}\text { E. Średnia długość pobytu na } \\
\text { terenie parku }\end{array}$ & $\begin{array}{l}1-1 \text { dzień } \\
2-1,1-3 \mathrm{dni} \\
3-3,1-5 \mathrm{dni} \\
4-5,1-7 \mathrm{dni} \\
5>7 \mathrm{dni}\end{array}$ & $\begin{array}{l}\text { BPN } \\
\text { GPN, MPN,PPN* } \\
\text { TPN }\end{array}$ \\
\hline $\begin{array}{l}\text { F. Udział (\%) turystów, będących } \\
\text { pierwszy raz w parku }\end{array}$ & $\begin{array}{l}1>40 \% \\
2-30,01-40,00 \% \\
3-20,01-30,00 \% \\
4-10,01-20,00 \% \\
5-0,00-10,00 \%\end{array}$ & $\begin{array}{l}\text { MPN, PPN } \\
\text { BPN } \\
\text { GPN } \\
\text { TPN }\end{array}$ \\
\hline $\begin{array}{l}\text { G. Udział (\%) turystów, dla któ- } \\
\text { rych park był bezpośrednim } \\
\text { celem podróży }\end{array}$ & $\begin{array}{l}1<30 \% \\
2-30,01-45 \% \\
3-45,01-60 \% \\
4-60,01-75 \% \\
5>75 \%\end{array}$ & $\begin{array}{l}\text { BPN, GPN, MPN } \\
\text { PPN } \\
\text { TPN }\end{array}$ \\
\hline
\end{tabular}

* Pieniński Park Narodowy został przesunięty o jedną klasę niżej ze względu na fakt, że badania ankietowe nie objęły uczestników splywu Dunajcem, których charakteryzują krótkie pobyty w parku.

$$
\text { Ź r ó d t o: Opracowanie własne. }
$$

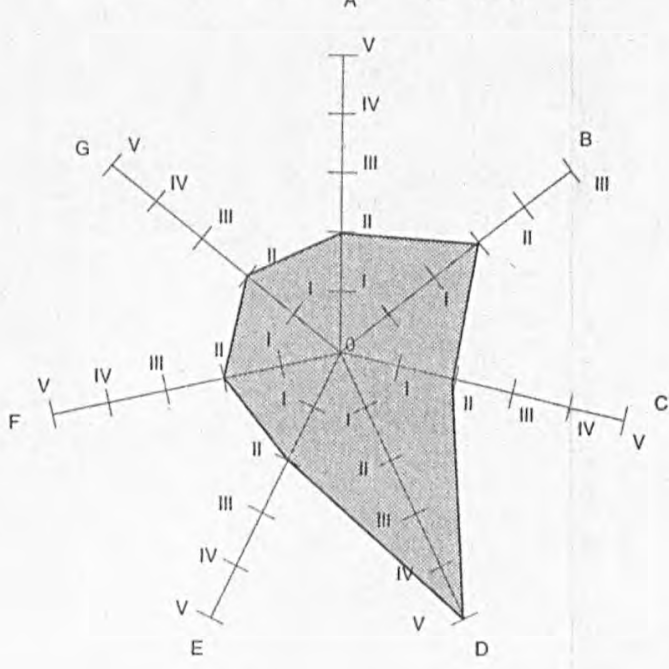

Magurski Park Narodowy (TYP II)

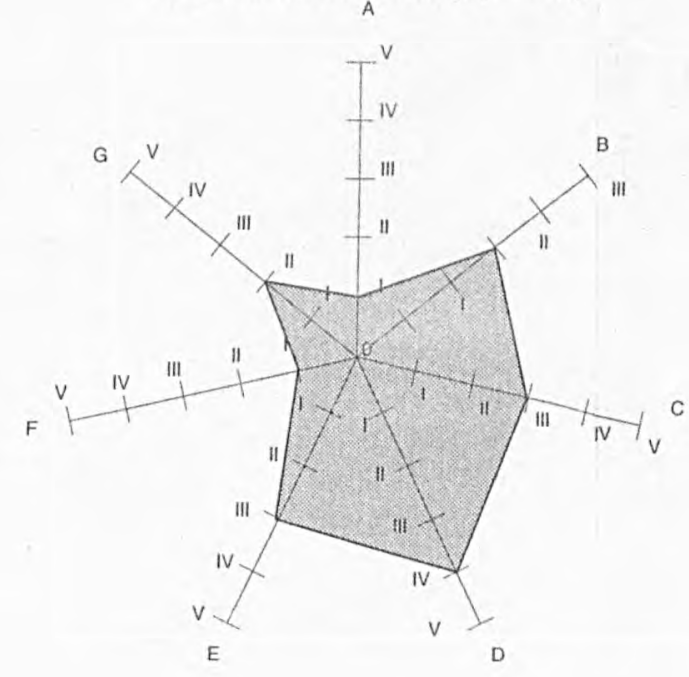

Tatrzański Park Narodowy (TYP V)

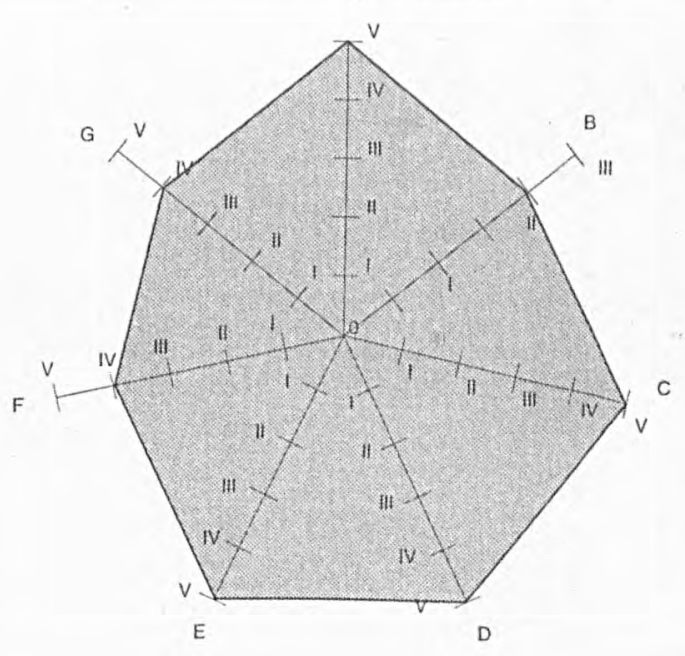

Gorczański Park Narodowy (TYP III)

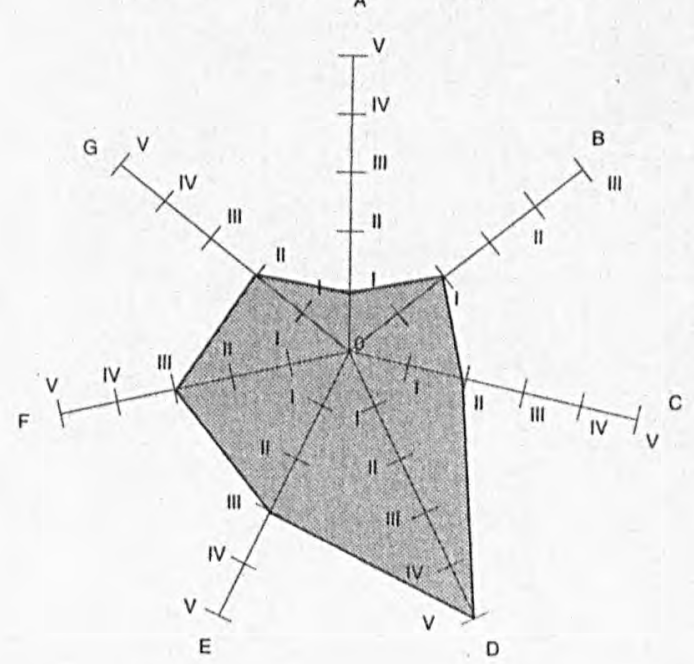

Pieniński Park Narodowy (TYP IV)

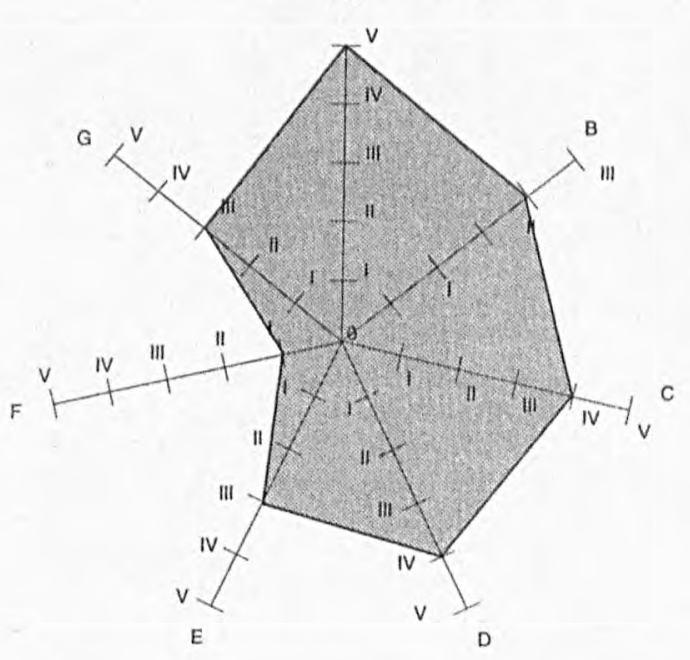

Rys. 12. Typy funkcjonalne parków narodowych w Karpatach Zachodnich (1996 r.)

A - Liczba turystów przypadająca na $1 \mathrm{~km}$ szlaku turystycznego; B - Współczynnik koncentracji przestrzennej ruchu turystycznego; C - Odległość liniowa od parku; D - Amplituda wielkości ruchu turystycznego: E - Średnia dlugość pobytu na terenie parku; F - Udział turystów, bedacych pierwszy raz w parku; $\mathrm{G}-$ Udział turystów, dla których park byì bezpośrednim celem podróży.

12. Les types fonctionneles des parcs nationaux des Karpates d'Ouest 1996

A - Nombre de touristes sur $1 \mathrm{~km}$ d'itinéraire touristique: B - Noefficient de concentration spatiale du mouvement touristique; C - Éloignement linéaire du parc; D - Amplitude de la grandeur du mouvement touristique; E - Longueur moyenne de séjour sur le terrain du parc; $F$ - Longueur moyenne de sejour des touristes visitant le parc pour la premiére fois; G - Part de touristes n' ayant d'autres buts que celui de visiteur le parc. 
miejsca zamieszkania a parkiem (C), sezonowość (D), długość pobytu na terenie parku $(E)$, udział pierwszych wizyt $(F)$ oraz cel podróży $(G)$.

W ramach każdego miernika $(A-G)$ wydzielono pięć klas, do których wg ustalonych kryteriów zaliczono badane karpackie parki narodowe (tab. XIV). Tworząc typy funkcjonalne przyjęto zasadę, że liczba punktów uzyskanych za przynależność do konkretnej klasy równała się liczbie określającej tę klasę ( 1 klasa -1 punkt, 5 klasa -5 punktów). Wobec powyższego, suma punktów możliwych do uzyskania wahała się od 7 do 35 . Wśród analizowanych parków narodowych można wymienić następujące typy funkcjonalne:

- typ II (12-17 p. - funkcja słabo rozwinięta) - Magurski Park Narodowy,

- typ III (18-23 p. - funkcja średnio rozwinięta) - Babiogórski, Gorczański Park Narodowy,

- typ IV (24-29 p. - funkcja dobrze rozwinięta) - Pieniński Park Narodowy,

- typ V (30-35 p. - funkcja bardzo dobrze rozwinięta) - Tatrzański Park Narodowy.

Graficznym obrazem typów funkcjonalnych parków narodowych jest typogram Uhorczaka, do konstrukcji którego wykorzystano wszystkie wymienione mierniki (rys. 12).

\section{PODSUMOWANIE}

Przeprowadzona analiza pozwala stwierdzić, że parki narodowe znajdujące się w Karpatach Zachodnich oprócz funkcji ochronnej, pełnią również funkcję turystyczną. Stopień rozwoju tej funkcji, jej rangę i charakter określają $\mathrm{m}$. in.: wielkość ruchu turystycznego, zasięg oddziaływania parku, sezonowość przyjazdów, dlugość pobytu na jego terenie, cele przyjazdów do parku i liczba odbywanych do niego wizyt.

\section{PIŚMIENNICTWO}

D e n is i u k Z., 1995, Ochrona przyrody i krajobrazu, [w:] Karpaty Polskie, J. Warszyńska (red.), UJ, Kraków, s. 13I-143.

G r o c h J.. Ku rek W., 1995, Turystyka, [w:] Karpaty Polskie, J. Warszyńska (red.), U.I, Kraków, s. 265-300.

J a r c z e w s k a M., S i e j k o w s k a A., 1997, Pieniński Park Narodowy jako obiekt turystyczny, maszynopis iv Katedrze Geografii Miast i Turyzmu, Łódź.

K 1 e i s c h m i d B., 1998, Funkcja turystyczna Leby, maszynopis w Katedrze Geografii Miast i Turyzmu Ut, tódź.

K r a k ow i a B B.. 1997, Zagospodarowanie turystyczne karpackich parków narodowych, „Turyzm", เ. 7, z. 2, s. 25-47. 
K r a k o w i a k B., 1999, Funkcja turystyczna parków narodowych w Karpatach Zachodnich, maszynopis pracy doktorskiej w Katedrze Geografii Miast i Turyzmu UL, Łódź.

P r z e c ł a w s k i K., 1996, Czlowiek a turystyka. Zarys socjologii turystyki, Kraków.

Rocznik statystyczny województwa bielskiego, 1997, 1998, WUS, Bielsko-Biala.

Rocznik Statystyczny województwa nowosadeckiego, 1997, 1998, WUS, Nowy Sącz.

R o g a l e w s k i O., 1975, Uwagi w sprawie zasad zagospodarowania przestrzennego tatrzańskiego regionu turystycznego, „Ruch Turystyczny”, z. 2, s. 179-182.

Z i a r k o w s k a A., 1992, Atrakcyjność turystyczna splywu przetomem Dunajca przez Pieniny, maszynopis pracy magisterskiej w Katedrze Geografii Miast i Turyzmu UŁ, Łódź.

Dr Beata Krakowiak

Studium Doktoranckie Geografii

Wplynęło:

Katedra Geografii Miast i Turyzmu

23 lutego $2000 \mathrm{r}$.

Uniwersytet Łódzki

ul. Kopcińskiego 31

90-14 Lódź

\section{RÉSUMÉ}

3 millions d'hommes ont visité les parcs nationaux des Karpates d'Ouest en 1996. Le plus grand nombre de touristes - 2,5 millions, $83 \%$, pénétraient le Parc National de Tatra; le second du point de vue du mouvement touristique était le Parc National de Pieniny, visité par 400000 touristes environ. Les autres parcs ont accueilli de 20000 à 45 000-49 000 touristes (ceux de Gorce et de Babia Góra). De la grandeur du mouvement touristique dans le groupe de parcs examinés décident avant tout les valeurs naturelles, les traditions touristiques de la région, l’âge des parcs nationaux, l'aménagement touristique du parc donné et de son entourage. Ici il faut souligner, que la formation du mouvement touristique dans les parcs présentés ne dépend seulement d'un des traits mentionnés, mais de plusieurs. La disposition temporelle du mouvement touristique dans les parcs nationaux des Karpates d'Ouest correspond à celle sur les terrains montagnards; les touristes y arrivent pendant toute l'année. Cependant la fréquence est la plus grande en été. Pendant cette saison les plus nombreux touristes visitent le Parc National de Pieniny ( $54 \%$ environ) et celui de Magura (57\% environ). La disposition plus réguliére caractèrise le Parc National de Tatra et celui de Babia Góra. L'amplitude de leur mouvement touristique est moindre (18\% environ).

Qant à l'âge des touristes dans les parcs examinés, il faut noter que dominent les personnes adultes (25-60 ans). Elles constituent 52-55\% des touristes dans les parcs de Tatra, de Babia Góra et de Pieniny et environ $60 \%$ dans le pare de Gorce. La jeunesse (18-24 ans) est relativement moins nombreuse. Mais eu égard au fait que ce groupe embrasse les personnes nées seulement en 7 années, leur participation est considérable, puisque elle compte 40-45\% environ dans les parcs de Gorce, de Babia Góra, de Pieniny et de Tatra, et 53\% environ dans le parc de Magura (parc de jeunes gens). Le groupe de touristes bien âgés est minime, il oscille entre 0,5 et $3,5 \%$ suivant le parc.

Parmi les touristes dans les pares nationaux des Karpates, ce sont les personnes qui ont obtenu l'instruction supérieure ( $40 \%$ ) ou secondaire (41-49\% environ). En général les personnes à l'instruction au moins secondaire constituent $85 \%$ environ des touristes dans le Parc National de Tatra et $94 \%$ environ dans celui de Pieniny.

La division ainsi formée prouve que ce sont les personnes mieux instruites dans le nombre général de touristes visitant les parcs nationaux. 
Le visiteurs des parcs nationaux en $91-96 \%$ environ sont citadins. Ils représentent de grandes agglomérations, telles que, Kraków, Łódź, Poznań, Warszawa, Wrocław. 61\% des touristes qui visitent le Parc National de Babia Góra et $71 \%$ des visiteurs du Parc National de Magura viennent de grandes villes qui dépassent 100000 habitants. Les résultats obtenus prouvent que le nombre de touristes venant d'une ville donnée correspond à la grandeur de cette ville, et que la grandeur d'une ville détermine le besoin du départ touristique. Vu l'orgine teritoriale des touristes, on peut conclure que les parcs particuliers ont l'importance nationale - les Parcs Nationaux de Tatra et celui de Pieniny, ou régionale - les Parcs Nationaux de Babia Góra, de Gorce, de Magura (l'étendue de l'influence spatiale à été fixée à la base de la valeur du coefficient de concentration et de la distance linéaire entre le parc et le lieu ordinaire d'habitation).

Parmi les touristes visitant les parcs nationaux analysés, il y a des personnes qui y arrivent pas pour la premiére fois. Elles constituent un groupe pénétrant le parc (plus d'une visite, pas plus de dix) ou s'assimilant au parc (plus de dix visites). La participation du deuxième groupe est la plus grande dans le Parc National de Tatra (19\% environ) et celui de Gorce ( $16 \%$ environ), la plus petite dans le Parc National de Pieniny ( $3 \%$ environ). Parmi ceux qui arrivent pour la première fois dans les parcs nationaux des Karpates le plus grand nombre visitent le Parc National de Magura $(50 \%$ cnviron) et de Pieniny ( $43 \%$ environ), le moindre nombre de touristes se rendent au Parc National de Tatra ( $18 \%$ environ).

Quant à la longueur du séjour une certaine spécialisation se fait voir: on reste le plus longtemps (plus de 7 jours) dans le Parc National de Tatra (le but y est atteint), les séjours de courte ou moyenne durée dominent dans les Parcs Nationaux de: Babia Góra, Gorce, Magura et Pieniny. On y atteint son but, on traverse le parc pour aller plus loin, on se repose non loin du parc et le visite à l'occasion.

Le motif's essentiels des arrivées dans les pares nationaux des Karpates d'Ouest sont: le besoin du contact avec la nature, le désir de faire connaissance du terrain et le besoin de changer de milieu. Les parcs analysés sont en état de satisfaire à ces demandes.

L'importance des autres motifs se révèle en tant que trait individuel des parcs particuliers.

A la base des analyses détaillées, on a déterminé le degré de la fonction touristique et designé les types foncionnels des parcs nationaux examinés. Parmi les plus importants étalons, dans cette partie de l'ouvrage, on a reconnu: la grandeur du mouvement touristique (A), l'étendue de l'influence du parc exprimée par le coefficient de concentration (B) et la distance linéaire entre le lieu ordinaire d'habitation et le parc (C), le caractère saisonnier (D), la longuer du séjour sur le terrain du parc $(E)$, le part de premières visites $(F)$ et le but de voyage $(G)$.

Dans le cadre de chaque étalon $(A-G)$ on a distinqué 5 classes dans lesquelles on a compté selon les critères déterminés les pares nationaux des Karpates (Tabl. III).

Parmi les parcs nationaux examinés il y a des types comme suit:

- Type II - (la fonction faiblement développée) - Parc National de Magura, de Gorce,

- Type III - (la fonction médiocrement développée) - Parcs Nationaux de Babia Góra et celui

- Type IV - (la fonction bien développée) - Parc National de Pieniny,

- Type V - (la fonction trés bien développée) - Parc National de Tatra.

Traduit par Lucjan Kowalski

\section{SUMMARY}

In 1996 the national parks in the West Carpathians were visited by c. 3 million people. The most penetrated one was the Tatra National Park, which was visited by about 2.5 million tourists 
(83\%). The next most frequently visited one was the Pieniński National Park - about 400000 guests. The remaining national parks were visited by smaller numbers: from c. 20000 (Magurski National Park) to c. 45-49 000 tourists (the Gorczański and Babiogórski National Parks). The intensity of the tourist traffic in the group of parks under study is determined by their natural assets, tourist traditions in the region, the age of the national parks, as well as the tourist infrastructure of a park and its surroundings. It is worth pointing out that the tourist traffic in the parks under discussion is modified not by one of the above factors, but most often by several of them.

The time distribution of the tourist traffic in the national parks in the West Carpathians is linked to the distribution of the tourist traffic in the mountain region in general - tourists arrive here throughout the whole year. The busiest tourist time, however, is the summer. In this period the largest number of tourists visit the Pieniński (c. 54\%) and the Magurski National Parks (c. 57\%). A more even distribution of the tourist traftic occurs in the Tatra and Babiogórski National Parks - in their cases the amplitude of the tourist traffic is the smallest (c. 18\%).

As far as the age of the tourists is concerned, adult people (25-60 years of age) predominate $52-55 \%$ in the Tatra, Babiogorski and Pieniński National Parks, and up to $60 \%$ in the Gorczański National Park. Relatively fewer tourists are the young people (18-24 years of age). However, considering the fact that this group covers only seven birth years, its participation at $40-45 \%$ in the Gorczański, Babiogórski, Pieniński and Tatra National Parks and c. 53\% in the Magurski National Park should be treated as very large. The smallest percentage of tourists refers to the oldest group. Depending on the park, its participation is from $0,5 \%$ to about $3,5 \%$.

Among the tourists visiting the national parks in the West Carpathians the largest group have gone through university education (c. 40-45\%) or college education (c. 41-49\%). All in all, people with at least college education make between $85 \%$ of the tourists in the Tatra National Park and c. $94 \%$ in the Pieniński National Park. Such a distribution proves a definite majority of better educated people in the general number of tourists visiting the national parks under study.

The visitors to national parks mostly come from cities - $91-96 \%$. The largest numbers arrive from big urban agglomerations, like Cracow, Lódź, Poznań, Warsaw, Wrocław. All in all, inhabitants of towns and cities of above 100000 residents make c. $61 \%$ of tourists visiting the Babiogórski National Park and c. $71 \%$ coming to the Magurski National Park. The data obtained prove that the number of tourists arriving from a given city corresponds to its size, and that the size of the city modifies the need for a tourist trip.

As far as the territorial origins of the tourists are concerned, individual national parks can be given either the national importance: The Tatra and the Pieninski National Parks, or regional importance - the Babiogórski, Gorczański, Magurski National Parks (the range of the spatial influence of the parks under discussion was established on the basis of the concentration quotient and the linear distance between the park and place of residence).

Among the tourists visiting the parks under study, there is a dominating group of people who have visited a given park before. They are people who penetrate the park (more than one visit, not more than ten), as well as those assimilated to the park (more than ten visits). The participation of the latter is the largest in the Tatra (c. 19\%) and the Gorczański (c. 16\%) National Parks; the smallest in the Pieniński National Park (c. 3\%). Among the tourists who arrive at the national parks in the West Carpathians for the first time, the largest group visit the Magurski (c. 50\%) and Pieniński (c. 43\%) National Parks, and the smallest group visit the Tatra National Park (c. 18\%).

As far as the length of stay and purpose of coming are concerned one can notice a certain specialization - long stays (above 7 days) dominate in the Tatra National Park (it is the final destination), medium-length and short stays dominate in the Babiogórski, Gorczański, Magurski and Pieniński National Parks (mixed character of the parks - they are stages of a trip, tourists are on holidays in the vicinity).

The basic reasons for coming to the national parks in the West Carpathians are: the need for staying in touch with nature, getting to know the area and the need for changing the environment. 
In all the parks under discussion these reasons are predominant. The importance of other reasons becomes visible as an individual feature of individual parks.

By thorough analyses the development of the tourist function was defined and the functional types of the national parks under study were established. In this part of the study the most important factors were: the intensity of the tourist traffic $(A)$, the scope of influence of a given park, expressed by the concentration coefficient (B) and the linear distance between the place of residence and a given park $(C)$, seasonality (D), length of stay in the park area (E), the percentage of the first visits $(F)$ and the purpose of the trip $(\mathrm{G})$.

Within each factor (A-G) five classes were isolated, in which, according to certain criteria, the Carpathian national parks under study were included (Table 3). Among the parks there are representatives of the following types:

- type II (weak function) - Magurski National Park,

- type III (fairly developed function) - Babiogórski National Park,

- type IV (well developed function) - Pieniński National Park,

- type V (strong/very well developed function) - Tatra National Park.

Translated by Ewa Mossakowska 